\title{
Dating tectonic activity in the Lepontine Dome and Rhone-Simplon Fault regions through hydrothermal monazite-(Ce)
}

\author{
Christian A. Bergemann ${ }^{1,2, a}$, Edwin Gnos ${ }^{1}$, Alfons Berger ${ }^{3}$, Emilie Janots $^{4}$, and Martin J. Whitehouse ${ }^{5}$ \\ ${ }^{1}$ Natural History Museum of Geneva, Geneva, Switzerland \\ ${ }^{2}$ Department of Earth Sciences, University of Geneva, Geneva, Switzerland \\ ${ }^{3}$ Institute of Geological Sciences, University of Bern, Bern, Switzerland \\ ${ }^{4}$ ISTerre, University of Grenoble, Grenoble, France \\ ${ }^{5}$ Swedish Museum of Natural History, Stockholm, Sweden \\ ${ }^{a}$ currently at: Institute of Earth Sciences, Heidelberg University, Heidelberg, Germany
}

Correspondence: Christian A. Bergemann (christian.bergemann@unige.ch)

Received: 21 January 2019 - Discussion started: 5 February 2019

Revised: 10 January 2020 - Accepted: 20 January 2020 - Published: 21 February 2020

\begin{abstract}
Zoned hydrothermal monazite-(Ce) from Alpinetype fissures and clefts is used to gain new insights into the tectonic history of the Lepontine Dome in the Central Alps and the timing of deformation along the RhoneSimplon Fault zone on the dome's western end. Hydrothermal monazites-(Ce) (re)crystallization ages directly date deformation that induces changes in physicochemical conditions of the fissure or cleft fluid. A total of 480 secondary ion mass spectrometry (SIMS) spot analyses from 20 individual crystals, including co-type material of the monazite-(Nd) type locality, record ages for the time of $\sim 19$ to $2.7 \mathrm{Ma}$, with individual grains recording age ranges of 2 to $7.5 \mathrm{Myr}$. The combination of these age data with geometric considerations and spatial distribution across the Lepontine region gives a more precise young exhumation history for the area. At the northeastern and southwestern edges of the Lepontine Dome, units underwent hydrothermal monazite-(Ce) growth at 1912.5 and 16.5-10.5 Ma, respectively, while crystallization of monazite-(Ce) in the eastern Lepontine Dome started later, at 15-10 Ma. Fissure monazite-(Ce) along the western limit of the dome reports younger ages of 13-7 Ma. A younger age group around $8-5 \mathrm{Ma}$ is limited to fissures and clefts associated with the Simplon normal fault and related strike-slip faults such as the Rhone Fault. The data set shows that the monazite-(Ce) age record directly links the fluid-induced interaction between fissure mineral and host rock to the Lepontine Dome's evolution in space and time. A comparison between hydrothermal monazite-(Ce) and thermochronometric
\end{abstract}

data suggest that hydrothermal monazite-(Ce) dating may allow us to identify areas of slow exhumation or cooling rates during ongoing tectonic activity.

\section{Introduction}

Metamorphic domes often experience a multiphase tectonometamorphic evolution (e.g., Schmid et al., 2004; Steck et al., 2013). For the Lepontine Dome of the European Alps, this evolution is an interplay between exhumation and deformation during doming and motion along large fault systems that dominate the western regions of the dome. Although much of the retrograde orogenic evolution of the area is well known (e.g., Hurford, 1986; Mancktelow, 1992; Steck and Hunziker, 1994; Mullis et al.,1994; Wiederkehr et al., 2009; Campani et al., 2010; Haertel et al., 2013; Steck et al., 2013), hydrothermal monazite-(Ce) ages may complement existing cooling ages of thermochronometers by providing crystallization and dissolution-precipitation ages that directly date low-temperature $(T)$ tectonic activity.

Monazite, a light rare-earth-element (LREE) mineral with composition (LREE, Th, U)PO $\mathrm{P}_{4}$, is considered an excellent mineral for the dating of geologic processes (e.g., Parrish, 1990). It is highly resistant to radiation damage (e.g., Meldrum et al., 1998, 1999, 2000) and shows negligible $\mathrm{Pb}$ loss by diffusion (Cherniak et al., 2004; Cherniak and Pyle, 2008). Nonetheless, monazite may record ages after 
its initial crystallization, as it can experience dissolutionreprecipitation or recrystallization facilitated by hydrous fluids (e.g., Seydoux-Guillaume et al., 2012; Janots et al., 2012; Grand'Homme et al., 2016).

Fissures and clefts, occasionally containing hydrothermal monazite-(Ce), represent voids partially filled with crystals that precipitated on the fissure walls from hydrous fluids during late-stage metamorphism (Mullis et al., 1994; Mullis, 1996). Dating such mineralization is often difficult due to later overprinting during multiple stages of fluid activity (Purdy and Stalder, 1973). Fissures and clefts in some metasediments and metagranitoids have long been known to contain well-developed monazite-(Ce) crystals (Niggli et al., 1940), but it is only recently that some of these were dated (e.g., Gasquet et al., 2010; Janots et al., 2012). While other minerals like micas and adularia are common in alpine fissures, these are often affected by overpressure or excess argon (e.g., Purdy and Stalder, 1973). Another issue is that it is not always clear whether these ages represent (re)crystallization or cooling through system closure to diffusion (e.g., Rauchenstein-Martinek, 2014). In contrast, hydrothermal monazite-(Ce) dates new crystallization or recrystallization but provides only a very general idea of the temperature. The fissures and clefts in the Lepontine region formed after the metamorphic peak, in the context of extensional tectonic activity. Accordingly, fissures and clefts are oriented roughly perpendicular to the lineation and foliation of the host rock. The fluid that intruded during fissure formation $\left(<\right.$ ca. $450^{\circ} \mathrm{C}$; Mullis et al., 1994; Mullis, 1996) interacted with the wall rock, triggering dissolution and precipitation of minerals in both host rock and fissure, marked by a porous alteration halo in the surrounding wall rock. Complex growth domains are common in hydrothermal monazite(Ce) from such fissures showing both dissolution and secondary growth (e.g., Janots et al., 2012; Bergemann et al., 2017, 2018), as well as dissolution-reprecipitation reactions resulting in patchy grains (e.g., Gnos et al., 2015). In contrast to metamorphic rocks, where newly formed monazite(Ce) rarely exceeds $100 \mu \mathrm{m}$, fissure monazite-(Ce) is commonly millimeters in size, containing large individual growth domains. This enables precise dating of individual domains using secondary ion mass spectrometry (SIMS). Thereby allowing researchers to resolve growth duration and identify single events and phases of tectonic activity (e.g., Janots et al., 2012; Berger et al., 2013; Bergemann et al., 2017, 2018, 2019b).

The formation of hydrothermal monazite-(Ce) within an open fissure or cleft depends on the chemical composition of the aqueous fluid filling it. Following the initial formation of a fissure or cleft, the intruding fluid $\left(<\mathrm{ca} .450{ }^{\circ} \mathrm{C}\right.$; Mullis et al., 1994; Mullis, 1996) leaches and partly dissolves the surrounding host rock, leading to crystallization of mineral phases on the fissure or cleft wall until a chemical equilibrium is reached. If the resulting chemical equilibrium between fluid phase, cleft minerals, and those parts of the wall rock accessible to the fluid is disturbed, a new cycle of dissolution and crystallization within the cleft occurs. Quartz fluid inclusion studies show that its growth is not continuous (thus not due to a continuous temperature drop) but stepwise (e.g., Mullis, 1996). Independent of the initial fluid, it has a strongly rock-buffered composition. This is, for example, expressed by matching stable oxygen values of hydrothermal quartz and quartz from the host rock (e.g., Sharp et al., 2005), implying a low fluid-to-rock ratio and minimal fluid flow. Moreover, the composition of the fissure-filling fluid changes systematically according to the maximal metamorphic grade reached during regional metamorphism (e.g., RauchensteinMartinek et al., 2016). This indicates that the initial fissure fluid is sourced from the surrounding country rock instead of large-scale fluid flow. Thus, chemical disequilibration is generally triggered by tectonic activity, causing a deformation of the fissure or cleft, and results in sudden changes in the $P-T$ conditions, the influx or loss of fluid, or the exposure of previously unaltered wall rock (e.g., Mullis et al., 1994; Rolland et al., 2003; Sharp et al., 2005). While fluids released during dehydrating mineral reactions play an important role during prograde burial and metamorphism, the type of cleft sampled in the context of this study forms under retrograde conditions (e.g., Mullis et al., 1994; Mullis, 1996; Sharp et al., 2005; Rauchenstein-Martinek et al., 2016). The fissure or cleft remains fluid filled and behaves for considerable parts of its history as a closed system (e.g., Sharp et al., 2005). This was deduced from the fluid volumes required for the precipitation of the encountered hydrothermal minerals being too large. This issue necessitates a recycling of an entrapped fluid in multiple dissolution-precipitation cycles that would need to be triggered by deformation of the system, so that small volumes of fluid suffice for the (re)precipitation of large mineral volumes. Most likely a complete reopening of the system only happens at a relatively late stage when all country rocks become brittle, independent of their mineral composition, or in association with steeply oriented shear and fault zones that create a pathway for penetration of meteoric water (e.g., Sharp et al., 2005; Bergemann et al., 2018) or for fluids from depth (e.g., Janots et al., 2019). The penetration of meteoric water into a fissure will typically lead to a dilution of the fissure fluid and an end of monazite crystallization. This means that while an age in an individual crystal might, in rare cases, record fluid flow unassociated with deformation, previous studies suggest that this is not the norm (Berger et al., 2013; Grand'Homme et al., 2016; Bergemann et al., 2017, 2018, 2019b; Ricchi et al., 2019). Consequently, individual ages found in one crystal of an area have therefore an uncertainty in what they date; deformation is most likely dated if several crystals of an area record the same age.

The mechanisms of (partial) dissolution and precipitation of newly formed cleft minerals occur repeatedly, resulting in the strong zonation, alteration, and dissolution features of most cleft minerals (e.g., Mullis, 1996; Sharp et al., 2005; Heijboer, 2006). Thus, the mineral association of a cleft is 


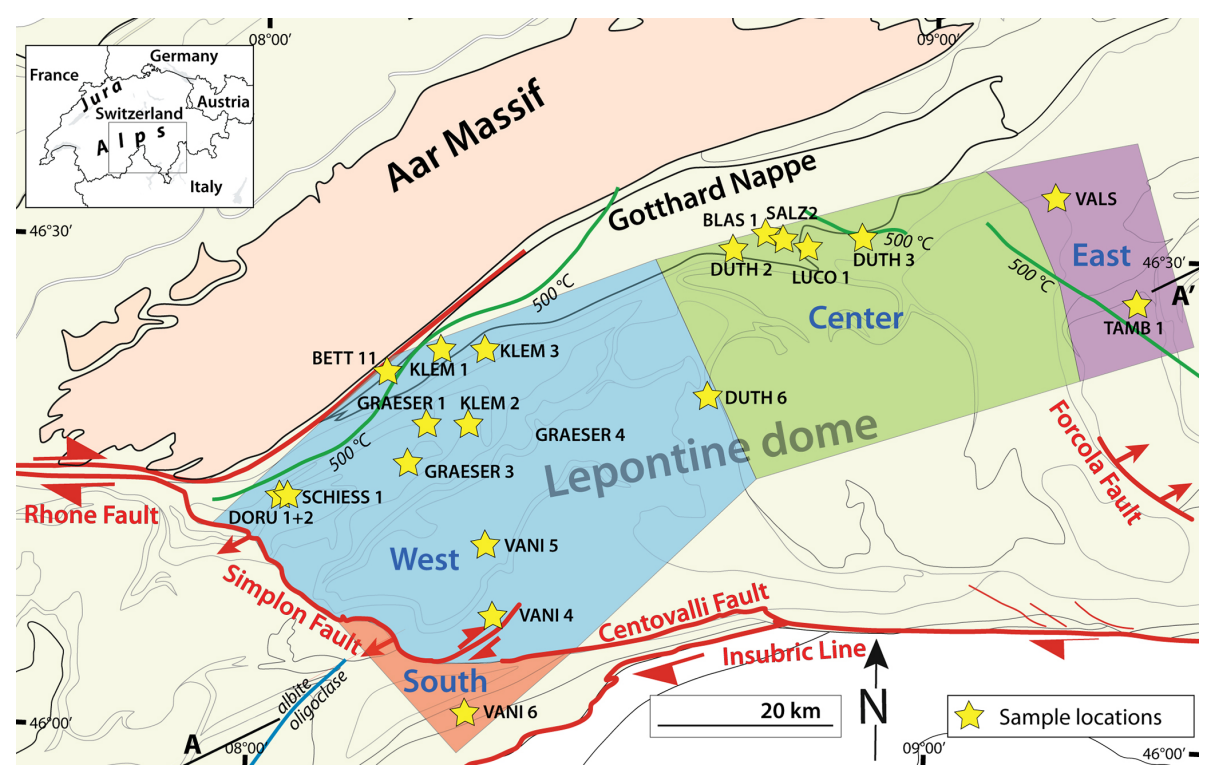

Figure 1. Map of the Lepontine Dome, modified from Steck et al. (2013) and Schmid et al. (2004). Colored areas mark the areal division in the context of this study. The $500{ }^{\circ} \mathrm{C}$ isograd was taken from Todd and Engi (1997) and Wiederkehr et al. (2008), and the albite-oligoclase mineral zone boundary was taken from Beard (1958). Section A-A' is shown in Fig. 6.

the result of a series of disequilibrations, and it does not represent a mineral paragenesis. This means that each crystal or crystal part formed due to a disequilibration of the system, and it was, after its formation, in chemical equilibrium with the surrounding fluid. Therefore, each primary chemical zone within a crystal represents a change in the cleft fluid chemical composition.

Hydrothermal monazite-(Ce) typically crystallizes at temperatures below $\sim 350$ or $\sim 300^{\circ} \mathrm{C}$ (Gnos et al., 2015; Bergemann et al., 2017, 2018). Due to the continued presence of fluid in the cleft, it continues to be able to record ages down to at least $200^{\circ} \mathrm{C}$ and likely below (e.g., Townsend et al., 2000; Bergemann et al., 2017, 2018). During the formation of a grain, any tectonic activity that changes the chemical equilibrium within a cleft causes the crystal to develop a primary chemical zonation usually visible in backscattered electron (BSE) images. After crystallization, monazite-(Ce) shows practically no U-Th- $\mathrm{Pb}$ diffusion at the prevalent $P-T$ conditions (Cherniak and Pyle, 2008). However, the changing chemical conditions in a hydrothermal environment may not only cause new growth around an existing grain but also can result in partial (re)crystallization/dissolution-reprecipitation in equilibrium with the cleft fluid (e.g., Janots et al., 2012; Bergemann et al., 2017; Grand'Homme et al., 2018). These dissolutionreprecipitation processes may be initiated on any part of the crystal in contact with the surrounding fluid. A selfsustaining reaction front propagates in this case into the mineral for as long as the interfacial fluid remains connected to a fluid reservoir (e.g., Putnis, 2002, 2009). Alteration is therefore not limited to grain rims but commonly occurs along mineral inclusion interfaces, cracks, and microcracks (Fig. 2a, b; Grand'Homme et al., 2018). Due to these processes, also internal parts of a crystal may be altered and in some cases even result in young core and old rim ages, possibly due to the interior grain parts being in stronger disequilibrium with the surrounding fluid. These processes may be active as long as conditions in the cleft stay within the monazite-(Ce) formation temperature window and stability field and appear to be largely temperature independent within this temperature window, with only slightly increasing reaction speeds with increasing temperature (Budzyn et al., 2011). Therefore, several (re)crystallization or dissolutionprecipitation cycles may occur over the active lifetime of a monazite-(Ce) crystal (e.g., Bergemann et al., 2018, 2019b). The dissolution-reprecipitation/recrystallization events commonly induce porosity and fractures in the monazite-(Ce) and catalyze later reactions by bringing an increased crystal volume into direct contact with the fluid (Putnis, 2002, 2009). This is observable in both primary monazite-(Ce) that formed during the initial formation of the grain and secondary monazite-(Ce) that formed at a later time or due to dissolution-reprecipitation/recrystallization. Possible signs of these alteration processes recognizable in BSE images are irregularly shaped (Fig. 2a, b) or weak (Fig. 2b) internal zonation or cross-cutting by secondary zones (Fig. $5 \mathrm{j}$, k), as well as a high porosity (Fig. 2a, b; e.g., Gnos et al., 2015; Bergemann et al., 2017, 2018). Microscale alteration along cracks, inclusions, and porosity may produce altered areas within a crystal that cannot be recognized in BSE images but yield a different age, as assumed for the crystal shown in Fig. 2c (Grand'Homme et al., 2018). Dissolution- 

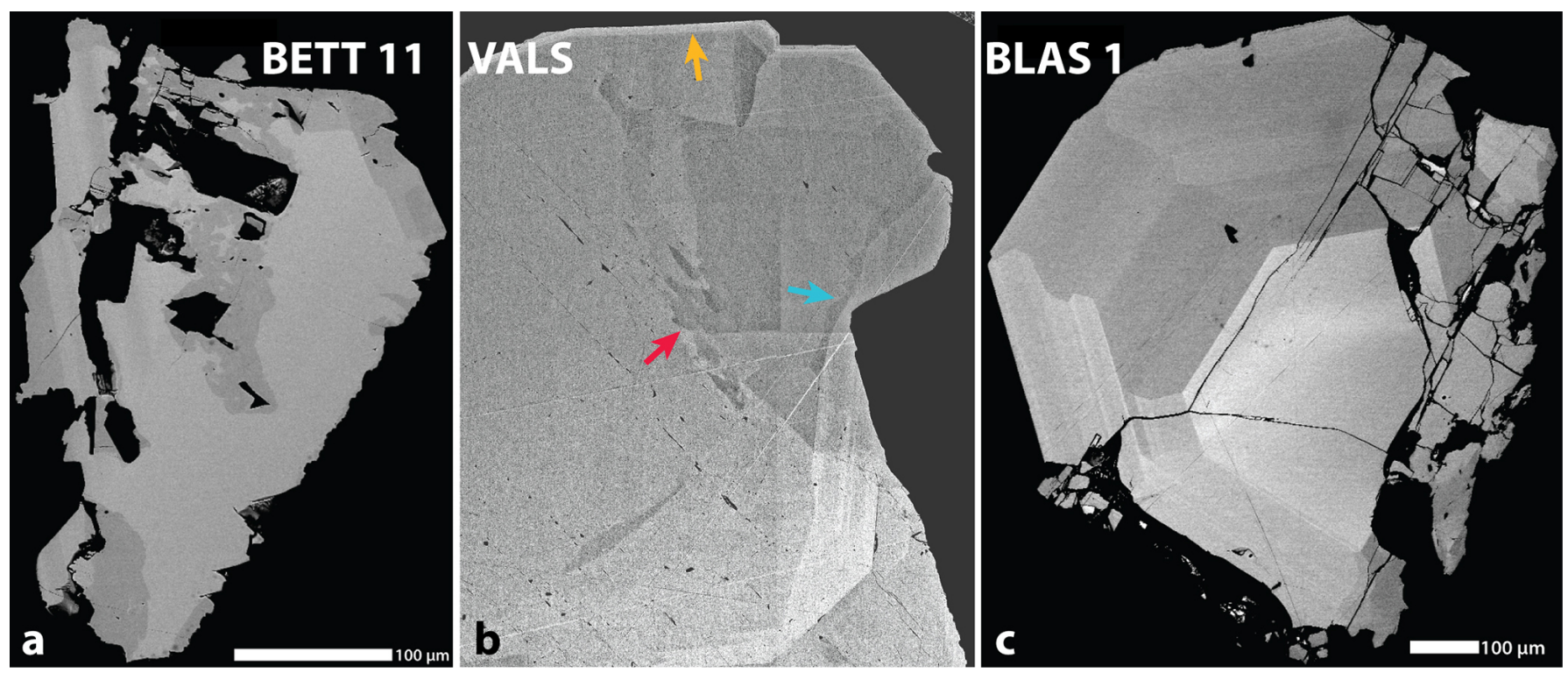

Figure 2. Backscattered electron (BSE) images of monazite-(Ce) samples showing different kinds of internal primary and alteration structures. (a) The dark grain areas of the grain, primarily located close to rims and inclusions, display sharp irregularly shaped borders and porosity. These areas consist of secondary monazite that is ca. 2.5 Myr younger than the lighter grain parts (Fig. 5b). Panel (b) shows part of a large grain with partially preserved sector-like zonation. Indications for alteration are irregularly shaped secondary zonation, both patchy in the middle (red arrow) and wavy on the right side (blue arrow), as well as porosity and fractures. The light rim visible at the top (orange arrow) likely represents a late overgrowth but yields some of the oldest ages of the grain, predating those of some of the interior grain parts by several million years (Fig. 5t). The grain in (c) displays multiple rims combined with sector-like zonation around the core. Although the grain shows practically no alteration features, the outer rim has the oldest and most homogeneous age pattern, with the central part possessing a wider age range with some significantly younger ages (Fig. 5m, Table S1 in the Supplement). The youngest ages were found in part of the inner rim surrounding the core, postdating all other ages measured in the second rim or center by several million years.

precipitation processes may sometimes largely preserve the chemical composition of an affected crystal part, possibly due to only small pore fluid volumes involved in the reaction that did not equilibrate completely with the fluid surrounding the crystal; consequently, areas affected by alteration that possess different chemical compositions may have reprecipitated simultaneously (Grand'Homme et al., 2016; Bergemann et al., 2017, 2018).

The aim of this study is to illustrate that hydrothermal monazite-(Ce) dating provides information about the tectonic evolution of metamorphic domes and their surrounding areas using the example of the Lepontine Dome.

\section{Geological setting}

\subsection{Evolution of the study area}

The formation of the nappe stack of the European Alps, caused by the collision of the European and Adriatic plates, was followed by the development of several domes (Tauern and Rechnitz in the Eastern Alps and Lepontine in the Central Alps; e.g., Schmid et al., 2004). Dome formation was related to crustal shortening associated with coeval orogen- parallel extension (e.g., Mancktelow, 1992; Ratschbacher et al., 1989, 1991).

Early high-pressure $(P)$ metamorphism in the western Alpine Sesia-Lanzo Zone during subduction below the Southern Alps is dated to 75-65 Ma (e.g., Ruffet et al., 1997; Rubatto et al., 1998; Regis et al., 2014). This was followed by underthrusting and nappe stacking from ca. $42 \mathrm{Ma}$ on, during continental collision linked with a transition from high $P$ and low $T$ to Barrow-type metamorphism of mediumgrade conditions of $\geq 500^{\circ} \mathrm{C}$ in most of the Lepontine Dome (e.g., Köppel and Grünenfelder, 1975; Markley et al., 1998; Herwartz et al., 2011; Boston et al., 2017). Peak metamorphic conditions were reached diachronously from south to north around 30-19 Ma (e.g., Schärer et al., 1996). Barrovian metamorphism was followed by exhumation starting in the east and moving westward within the Lepontine Dome, with vertical displacement along the Insubric Line starting as early as $30 \mathrm{Ma}$ (e.g., Hurford, 1986; Steck and Hunziker, 1994). Accelerated cooling due to exhumation below $500^{\circ} \mathrm{C}$ first occurred at $\sim 26 \mathrm{Ma}$ in the central Lepontine Dome (Hurford, 1986). This was followed in the eastern Lepontine Dome and along the Insubric Line between 22 and 17 Ma by a period of rapid cooling (Steck and Hunziker, 1994; Rubatto et al., 2009), after which exhumation slowed down. The area 
to the west in the surroundings of the Rhone-Simplon Line experienced phases of accelerated cooling somewhat later at 18-15 and 12-10 Ma (Campani et al., 2014).

The western and southwestern margins of the study area (Fig. 1) are dominated by the Rhone-Simplon Fault system, its extensions to the Rhine-Rhone Line to the north along the Aar Massif, and the Centovalli Fault to the south. The extensional Simplon Fault zone (SFZ) was active contemporaneously with thrusting in the external Alpine domain (e.g., Grosjean et al., 2004), with the ductile-brittle transition of the SFZ constrained to the time between 14.5 and $10 \mathrm{Ma}$ (Campani et al., 2010). Brittle deformation of the SFZ and Centovalli Fault continued after this (Zwingmann and Mancktelow, 2004; Surace et al., 2011), with the youngest displacement activity dated to ca. 5-3 Ma (Campani et al., 2010).

\subsection{Study area}

The study area comprises a part of the Lepontine Dome in which mineralized fissures and clefts commonly occur (Fig. 1). It extends from the Tambo nappe, east of the Forcola Fault, across the central Lepontine Dome to the Simplon Fault in the west and southwest, to the south of the Simplon Fault, and to the southern Gotthard Nappe to the north (see Fig. 3 for the tectonic position of the samples). The 20 dated monazite-(Ce) samples were at the study outset divided into four areal groups that proved, with few adjustments, to be serviceable in the context of this work (Fig. 1). These are (1) the Adula nappe and the area to its east (East; 2 samples); (2) the Lepontine Dome east of the Verzasca anticline, including part of the southern Gotthard Nappe (Center; 5 samples); (3) the Lepontine Dome west of the Verzasca anticline, including the southwestern Gotthard Nappe and bound by the Rhone-Simplon Fault (West; 12 samples); and (4) the area south of the Centovalli and southern Simplon faults (South; 1 sample).

\section{Analytical techniques}

Most of the samples were provided by mineral collectors, as hydrothermal cleft monazite-(Ce) is uncommon and often difficult to detect in the field when covered by dirt or chlorite. Sample GRAESER 1 was provided by the Natural History Museum of Basel (identification number NMBa 10226) and sample VALS was provided by the Natural History Museum of Bern (identification number NMBE43124). The sampled clefts are vertically oriented, except for those located in the Gotthard Nappe where the sampled clefts are horizontal. See Table 1 for location details. Monazite-(Ce) samples were individually polished to the level of a central cross section across the grain and assembled in mounts of several grains. BSE images were obtained using a Zeiss DSM940A electron microscope at the University of Geneva and a beam current of $3.5 \mathrm{nA}$. As the surface of the mounts needs to remain flat for ion-probe dating, element mapping that would cause damage to the epoxy is not possible. SIMS spot measurements (Fig. 5) were taken according to visible domains in these images. As far as possible, spot measurements next to cracks were avoided, as the $\mathrm{Th}-\mathrm{Pb}$ isotope measurements may be disturbed in such areas due to unevenness in the sample surface (Janots et al., 2012; Berger et al., 2013).

$\mathrm{Th}-\mathrm{Pb}$ analyses were conducted at the Swedish $\mathrm{Mu}-$ seum of Natural History (Nordsim facility) on a CAMECA ims 1280 SIMS instrument. Analytical methods and correction procedures followed those described by Harrison et al. (1995), Kirkland et al. (2009), and Janots et al. (2012), using a $-13 \mathrm{kV} \mathrm{O}^{2-}$ primary beam of ca. $6 \mathrm{nA}$ and nominal $15 \mu \mathrm{m}$ diameter. The mass spectrometer was operated at $+10 \mathrm{kV}$ and a mass resolution of ca. $4300(M / \Delta M$, at $10 \%$ peak height), with data collected in peak hopping mode using an ion-counting electron multiplier. Unknowns were calibrated against monazite-(Ce) standard 44069 (Aleinikoff et al., 2006). Lead isotope signals were corrected for common $\mathrm{Pb}$ contribution using measured ${ }^{204} \mathrm{~Pb}$ and an assumed present-day $\mathrm{Pb}$ isotope composition according to the model of Stacey and Kramers (1975). The measurement of ${ }^{204} \mathrm{~Pb}$ is subject to an unresolvable molecular interference by ${ }^{232} \mathrm{Th}^{143} \mathrm{Nd}^{16} \mathrm{O}_{2}^{++}$, also affecting ${ }^{206} \mathrm{~Pb}$ and ${ }^{207} \mathrm{~Pb}$ to a lesser degree through replacement of ${ }^{16} \mathrm{O}$ by heavier $\mathrm{O}$ isotopes, which may result in an overestimation of common $\mathrm{Pb}$ concentrations. A correction was applied whenever the ${ }^{232} \mathrm{Th}^{143} \mathrm{Nd}^{16} \mathrm{O}_{2}^{++}$signal at mass 203.5 exceeded the average background signal on the ion-counting detector by 3 times its standard deviation. Age calculations use the decay constants recommended by Steiger and Jäger (1977). The Th$\mathrm{Pb}$ ages were corrected for common $\mathrm{Pb}$ and doubly charged ${ }^{232} \mathrm{Th}^{143} \mathrm{Nd}^{16} \mathrm{O}_{2}^{++}$overlap, and they are reported with $2 \sigma$ uncertainties. Weighted mean age plots were done using Isoplot v. 3.75 (Ludwig, 2012).

\section{Th-Pb monazite-(Ce) dating and age calculation}

The dating of hydrothermal monazite-(Ce) differs from thermochronometers that possess a closure temperature insofar as a crystal may record several ages due to new crystallization or alteration of crystal parts. The grains directly record tectonic activity instead of cooling through new crystallization or recrystallization, e.g., in the case of $\mathrm{Ar}-\mathrm{Ar}$ dating in white micas. Consequently, unless coupled with fluid inclusion analysis, a hydrothermal monazite-(Ce) age in itself only provides a very general idea of fluid temperature conditions (ca. $350{ }^{\circ} \mathrm{C}$ down to at least $200^{\circ} \mathrm{C}$ or somewhat below; Gnos et al., 2015; Bergemann et al., 2017, 2018) and more information on regional temperatures needs to come from comparison with thermo(chrono)meters.

The SIMS spot measurements were distributed on the basis of domains visible in BSE images, among these the cen- 


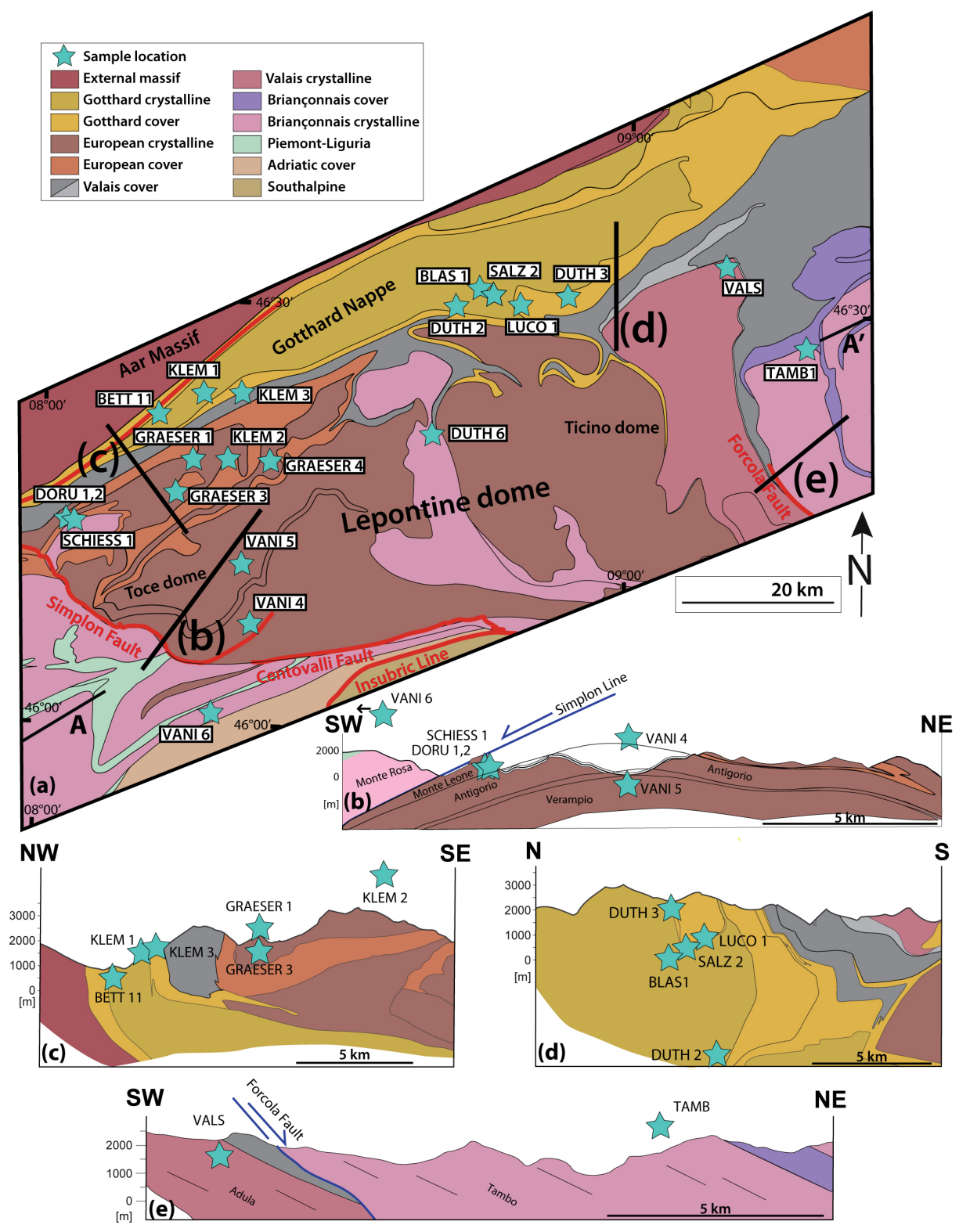

Figure 3. Tectonic overview over the study area. (a) Tectonic sketch map modified after Schmid et al. (2004) and Steck et al. (2013); (b) tectonic section over the Simplon Fault zone into the western Lepontine, based on Campani et al. (2014); (c) tectonic section through the western Northern Steep Belt, modified and extended after Leu (1986); (d) tectonic section through the eastern Northern Steep Belt, redrawn after Wiederkehr et al. (2008); (e) tectonic section across the Forcola normal fault; see also Meyre et al. (1998) and Berger et al. (2005). Profiles (b)-(e) are not to scale with map (a). Section A-A' is shown in Fig. 6.

ter and outer rims, if distinguishable, to capture the crystallization duration. In order to obtain more robust growth domain ages, the selected domains were large enough to place a minimum of three measurement spots. Only ${ }^{208} \mathrm{~Pb} /{ }^{232} \mathrm{Th}$ ages were used, as the $\mathrm{Th}-\mathrm{Pb}$ system is favorable in dating hydrothermal monazite-(Ce) due to high $\mathrm{Th} / \mathrm{U}$ ratios at low to very low $\mathrm{U}$ contents, which preclude the use of the ${ }^{207} \mathrm{~Pb} /{ }^{235} \mathrm{U}$ system. Additionally, the high $\mathrm{Th} / \mathrm{U}$ ratios and young age of the samples also exacerbate the uncorrectable excess in ${ }^{206} \mathrm{~Pb}$ due to the incorporation of ${ }^{232} \mathrm{Th}$, an in- termediate decay product of ${ }^{238} \mathrm{U}$ (Janots et al., 2012). Accordingly, only ${ }^{208} \mathrm{~Pb} /{ }^{232} \mathrm{Th}$ single or weighted mean ages instead of concordia ages should be used in this case.

Previous studies found no simple chemical criteria to identify altered zones and have shown that U-Th contents seem to be the easiest way to differentiate between zones, such as primary and often also secondary (e.g., Gnos et al., 2015; Bergemann et al., 2017). Figure 5 includes plots showing the compositional variation used as a basis for domain age calculations. The derived spot ages were grouped together on 
Table 1. Information on sample localities for all analyzed grains.

\begin{tabular}{lllllr}
\hline Region & Sample & Locality & Latitude & Longitude & Altitude (m) \\
\hline South & VANI 6 & Cava Maddalena, Beura & $46^{\circ} 04.30^{\prime}$ & $8^{\circ} 17.71^{\prime}$ & 260 \\
\hline \multirow{2}{*}{ West } & BETT 11 & Bettelbach, Niederwald, Goms & $46^{\circ} 25.62^{\prime}$ & $8^{\circ} 11.70^{\prime}$ & 1460 \\
& DORU1 & Doru, Gantertal, Simplon & $46^{\circ} 17.63^{\prime}$ & $8^{\circ} 02.07^{\prime}$ & 1160 \\
& DORU2 & Doru, Gantertal, Simplon & $46^{\circ} 17.64^{\prime}$ & $8^{\circ} 02.07^{\prime}$ & 1160 \\
& DUTH 6 & Pizzo Rüscada, Valle di Prato (Lavizzara) & $46^{\circ} 24.57^{\prime}$ & $8^{\circ} 40.09^{\prime}$ & 2420 \\
& GRAESER 1 & Lärcheltini, Binntal & $46^{\circ} 22.3^{\prime}$ & $8^{\circ} 14.9^{\prime}$ & 1860 \\
& GRAESER 3 & Wannigletscher, Cherbadung, Binntal & $46^{\circ} 19.5^{\prime}$ & $8^{\circ} 23.4^{\prime}$ & 2560 \\
& GRAESER 4 & Monte Giove, Val Formazza & $46^{\circ} 21.9^{\prime}$ & $8^{\circ} 13.0^{\prime}$ & 2720 \\
& KLEM 1 & Grosses Arsch, Blinnental & $46^{\circ} 26.71^{\prime}$ & $8^{\circ} 16.33^{\prime}$ & 1900 \\
& KLEM 2 & Alpe Devero, Val Antigorio & $46^{\circ} 22.16^{\prime}$ & $8^{\circ} 18.44^{\prime}$ & 2340 \\
& KLEM 3 & Griessgletscher & $46^{\circ} 26.59^{\prime}$ & $8^{\circ} 19.46^{\prime}$ & 2840 \\
& SCHIESS 1 & Schiessbach/Simplon & $46^{\circ} 18.13^{\prime}$ & $8^{\circ} 04.18^{\prime}$ & 1760 \\
& VANI 4 & Montecrstese & $8^{\circ} 19.18^{\prime}$ & 370 \\
& VANI 5 & Crino Baceno & $46^{\circ} 15.13^{\prime}$ & $8^{\circ} 19.14^{\prime}$ & 710 \\
\hline \multirow{2}{*}{ Center } & BLAS 1 & Piz Blas, Val Nalps, Sedrun & $46^{\circ} 34.68^{\prime}$ & $8^{\circ} 43.98^{\prime}$ & 2790 \\
& DUTH 2 & Lago Scuro, Val Cadlimo & $46^{\circ} 33.80^{\prime}$ & $8^{\circ} 41.50^{\prime}$ & 2620 \\
& DUTH 3 & Lago Retica, Lagi di Campo Blenio & $46^{\circ} 34.45^{\prime}$ & $8^{\circ} 53.57^{\prime}$ & 2400 \\
& LUCO 1 & Lucomagno & $46^{\circ} 33.79^{\prime}$ & $8^{\circ} 48.10^{\prime}$ & 1915 \\
& SALZ 2 & Piz Scai & $46^{\circ} 34.5^{\prime}$ & $8^{\circ} 45.8^{\prime}$ & 2740 \\
\hline East & TAMB 1 & Pizzo Tambo, Splügen & $46^{\circ} 30.48^{\prime}$ & $9^{\circ} 18.35^{\prime}$ & 2460 \\
& VALS & Vals, Valsertal & $46^{\circ} 37.3^{\prime}$ & $9^{\circ} 17.3^{\prime}$ & 3150 \\
\hline
\end{tabular}

the basis of spatial distribution across the sample according to zonation visible on BSE images and secondarily checked for chemical composition representing crystal formation or replacement under different chemical conditions of a given zone. Whenever age clusters were found on the basis of these groups, weighted mean domain ages were calculated (Fig. 5), as these could be shown to generally date tectonic activity (Berger et al., 2013; Grand'Homme et al., 2016; Bergemann et al., 2017, 2018, 2019b; Ricchi et al., 2019). Since any new crystallization or alteration associated with a change in chemical composition must have happened in equilibrium with the surrounding fluid, any age cluster within a chemical group must be due to the simultaneous formation or alteration of those crystal parts. Therefore, two chemically distinct groups that yield, within error, identical weighted mean ages still signify two distinct crystal formation or alteration events closely following each other. In areas that experienced strong and discrete tectonic events, usually in the vicinity of shear zones, this approach often allows for the calculation of domain ages for a majority of the analyzed spots from the data set of a sample (e.g., Janots et al., 2012; Berger et al., 2013; Bergemann et al., 2017, 2019b; Ricchi et al., 2019). As only a finite number of analyses can be obtained for each grain, some of the weighted mean ages may only combine a small number of individual ages. This appears to be especially true for ages dating late-stage events (e.g., Berger et al., 2013; Grand'Homme et al., 2016; Bergemann et al., 2017, 2018).
Differing from other areas from which hydrothermal monazite was studied, large parts of the Lepontine Dome region experienced multiple distinct deformation events and/or phases of prolonged small-scale tectonic activity, likely during exhumation, which led to a far more complex data set than those obtained for other areas (e.g., Janots et al., 2012; Berger et al., 2013; Grand'Homme et al., 2016; Bergemann et al., 2017, 2018, 2019b; Ricchi et al., 2019). Experiments have shown that a reason for the sometimes large age scatter found in crystal domains affected by alteration may be an incomplete age resetting within a crystal part due to the survival of primary monazite nanoscale domains (Grand'Homme et al., 2018). This may have caused the observed spread-out age patterns without age clusters in zones visible in BSE, which impede the calculation of weighted mean ages (Fig. 5). Especially prolonged phases of low-intensity tectonic activity would presumably repeatedly cause small volumes of monazite-(Ce) to reprecipitate during re-equilibration of the fluid chemistry. In those cases where no correlation between visible zonation and chemistry ( \pm ages) was found, the age data of a sample were submitted to an age deconvolution according to Sambridge and Compston (1994) using the Isoplot 3.75 Unmix function (Ludwig, 2012) to identify the number of age-group components. Where this did not yield well-constrained results, a mean squared weighted deviation (MSWD) test was applied to calculate a weighted mean age for the youngest and oldest age groups within a grain, with the remaining ages in be- 
Table 2. Overview list of the ${ }^{232} \mathrm{Th}-{ }^{208} \mathrm{~Pb}$ age range and significant minimum and maximum ages obtained for each grain and weighted mean domain ages that could be calculated for the samples.

\begin{tabular}{|c|c|c|c|c|c|c|c|c|c|c|}
\hline Region & Sample & Figure & $\begin{array}{r}\text { No. of } \\
\text { analyses }\end{array}$ & $\begin{array}{l}\text { Spot age range } \\
\text { of sample (Ma) }\end{array}$ & $\begin{array}{l}\min \text { age } \\
(\mathrm{Ma})\end{array}$ & $\begin{array}{l}\max \text { age } \\
(\mathrm{Ma})\end{array}$ & $\begin{array}{r}\text { Mean age } \\
(\mathrm{Ma})\end{array}$ & MSWD & $\begin{array}{l}\text { No. of } \\
\text { points }\end{array}$ & $\begin{array}{r}\text { Fraction } \\
\text { (unmixing) }\end{array}$ \\
\hline South & VANI 6 & $5 \mathrm{a}$ & 24 & $16.80 \pm 0.31-10.62 \pm 0.18$ & $16.80 \pm 0.31$ & $10.62 \pm 0.18$ & $14.68 \pm 0.47$ & 2.8 & 5 & \\
\hline \multirow[t]{28}{*}{ West } & BETT 11 & $5 b$ & 19 & $10.55 \pm 0.33-7.34 \pm 0.26$ & $10.31 \pm 0.31$ & like mean age & $9.85 \pm 0.29$ & 2.1 & 12 & \\
\hline & & & & & & & $7.53 \pm 0.31$ & 0.53 & 3 & \\
\hline & DORU 1 & $5 c$ & 25 & $10.82 \pm 0.26-8.21 \pm 0.20$ & like mean age & like mean age & $10.01 \pm 0.19$ & & & $0.45 \pm-$ \\
\hline & & & & & & & $9.47 \pm 0.24$ & & & $0.31 \pm 0.28$ \\
\hline & & & & & & & $8.41 \pm 0.17$ & & & $0.24 \pm 0.20$ \\
\hline & DORU 2 & $5 d$ & 32 & $11.48 \pm 0.28-7.02 \pm 0.18$ & $11.48 \pm 0.28$ & like mean age & $7.63 \pm 0.13$ & 0.55 & 8 & \\
\hline & & & & & & & $7.18 \pm 0.18$ & 0.50 & 4 & \\
\hline & DUTH 6 & $5 \mathrm{e}$ & 26 & $12.60 \pm 0.37-9.33 \pm 0.32$ & like mean age & like mean age & $11.92 \pm 0.26$ & 1.5 & 13 & \\
\hline & & & & & & & $9.74 \pm 0.22$ & 1.5 & 13 & \\
\hline & GRAESER 1 & $5 f$ & 31 & $12.14 \pm 0.30-7.57 \pm 0.19$ & like mean age & like mean age & $11.88 \pm 0.23$ & & & $0.19 \pm-$ \\
\hline & & & & & & & $10.18 \pm 0.24$ & & & $0.20 \pm 0.17$ \\
\hline & & & & & & & $8.93 \pm 0.14$ & & & $0.41 \pm 0.23$ \\
\hline & & & & & & & $7.73 \pm 0.17$ & & & $0.19 \pm 0.16$ \\
\hline & GRAESER 3 & $5 g$ & 17 & $15.60 \pm 0.61-6.36 \pm 0.39$ & $15.60 \pm 0.61$ & $6.36 \pm 0.39$ & & & & \\
\hline & GRAESER 4 & App. & 2 & $12.25 \pm 0.51-11.88 \pm 0.47$ & $12.25 \pm 0.51$ & $11.88 \pm 0.47$ & & & & \\
\hline & KLEM 1 & $5 \mathrm{~h}$ & 24 & $10.64 \pm 0.26-7.97 \pm 0.20$ & like mean age & like mean age & $10.34 \pm 0.24$ & & & $0.29 \pm-$ \\
\hline & & & & & & & $9.47 \pm 0.18$ & & & $0.41 \pm 0.27$ \\
\hline & & & & & & & $8.36 \pm 0.17$ & & & $0.29 \pm 0.22$ \\
\hline & KLEM 2 & $5 \mathrm{i}$ & 17 & $13.65 \pm 0.33-9.47 \pm 0.40$ & like mean age & like mean age & $13.44 \pm 0.32$ & & & $0.30 \pm-$ \\
\hline & & & & & & & $11.81 \pm 0.30$ & & & $0.24 \pm 0.22$ \\
\hline & & & & & & & $10.16 \pm 0.28$ & & & $0.35 \pm 0.29$ \\
\hline & KLEM 3 & $5 \mathrm{j}$ & 24 & $12.96 \pm 0.46-8.43 \pm 0.32$ & like mean age & like mean age & $12.24 \pm 0.35$ & 1.7 & 12 & \\
\hline & & & & & & & $8.9 \pm 1.2$ & 2.0 & 3 & \\
\hline & SCHIESS 1 & $5 \mathrm{k}$ & 27 & $9.94 \pm 0.25-6.78 \pm 0.18$ & like mean age & like mean age & $9.56 \pm 0.25$ & 2.0 & 10 & \\
\hline & & & & & & & $7.02 \pm 0.23$ & 1.6 & 7 & \\
\hline & VANI 4 & 51 & 16 & $9.27 \pm 0.43-6.89 \pm 0.37$ & $9.27 \pm 0.43$ & $6.89 \pm 0.37$ & $8.03 \pm 0.44$ & 2.2 & 7 & \\
\hline & VANI 5 & $5 \mathrm{~m}$ & 20 & $8.07 \pm 0.36-2.69 \pm 0.11$ & like mean age & $2.69 \pm 0.11$ & $7.22 \pm 0.27$ & 2.1 & 9 & \\
\hline & & & & & & & $5.27 \pm 0.31$ & 2.4 & 6 & \\
\hline \multirow[t]{9}{*}{ Center } & BLAS 1 & $5 n$ & 18 & $14.49 \pm 0.26-7.82 \pm 0.22$ & $14.49 \pm 0.26$ & $7.82 \pm 0.22$ & $12.83 \pm 0.39$ & 2.0 & 5 & \\
\hline & DUTH 2 & 50 & 16 & $14.34 \pm 0.41-11.15 \pm 0.43$ & $14.34 \pm 0.41$ & $11.15 \pm 0.43$ & $13.41 \pm 0.70$ & 2.0 & 5 & \\
\hline & DUTH 3 & $5 p$ & 26 & $14.53 \pm 0.43-10.61 \pm 0.34$ & like mean age & like mean age & $13.95 \pm 0.33$ & & & $0.41 \pm-$ \\
\hline & & & & & & & $12.73 \pm 0.35$ & & & $0.35 \pm 0.26$ \\
\hline & & & & & & & $10.95 \pm 0.33$ & & & $0.24 \pm 0.20$ \\
\hline & LUCO 1 & $5 q$ & 25 & $14.74 \pm 0.30-9.90 \pm 0.17$ & like mean age & like mean age & $14.30 \pm 0.21$ & 1.13 & 6 & \\
\hline & & & & & & & $10.14 \pm 0.42$ & 1.8 & 4 & \\
\hline & SALZ 2 & $5 \mathrm{r}$ & 28 & $14.28 \pm 0.74-10.51 \pm 0.39$ & like mean age & like mean age & $12.96 \pm 0.25$ & 2.4 & 20 & \\
\hline & & & & & & & $10.87 \pm 0.27$ & 1.14 & 8 & \\
\hline \multirow[t]{9}{*}{ East } & TAMB 1 & $5 \mathrm{~s}$ & 24 & $19.02 \pm 0.47-8.32 \pm 0.11$ & like mean age & $8.32 \pm 0.11$ & $18.85 \pm 0.77$ & & & $0.12 \pm-$ \\
\hline & & & & & & & $17.37 \pm 0.42$ & & & $0.23 \pm 0.21$ \\
\hline & & & & & & & $14.95 \pm 0.70$ & & & $0.24 \pm 0.22$ \\
\hline & & & & & & & $13.08 \pm 0.32$ & & & $0.41 \pm 0.28$ \\
\hline & VALS & $5 \mathrm{t}$ & 43 & $16.43 \pm 0.61-12.09 \pm 0.57$ & like mean age & like mean age & $15.27 \pm 0.35$ & 1.1 & 7 & \\
\hline & & & & & & & $14.77 \pm 0.42$ & 2.0 & 16 & \\
\hline & & & & & & & $14.70 \pm 0.41$ & 0.81 & 6 & \\
\hline & & & & & & & $13.80 \pm 0.49$ & 2.7 & 4 & \\
\hline & & & & & & & $12.94 \pm 0.49$ & 1.9 & 10 & \\
\hline
\end{tabular}




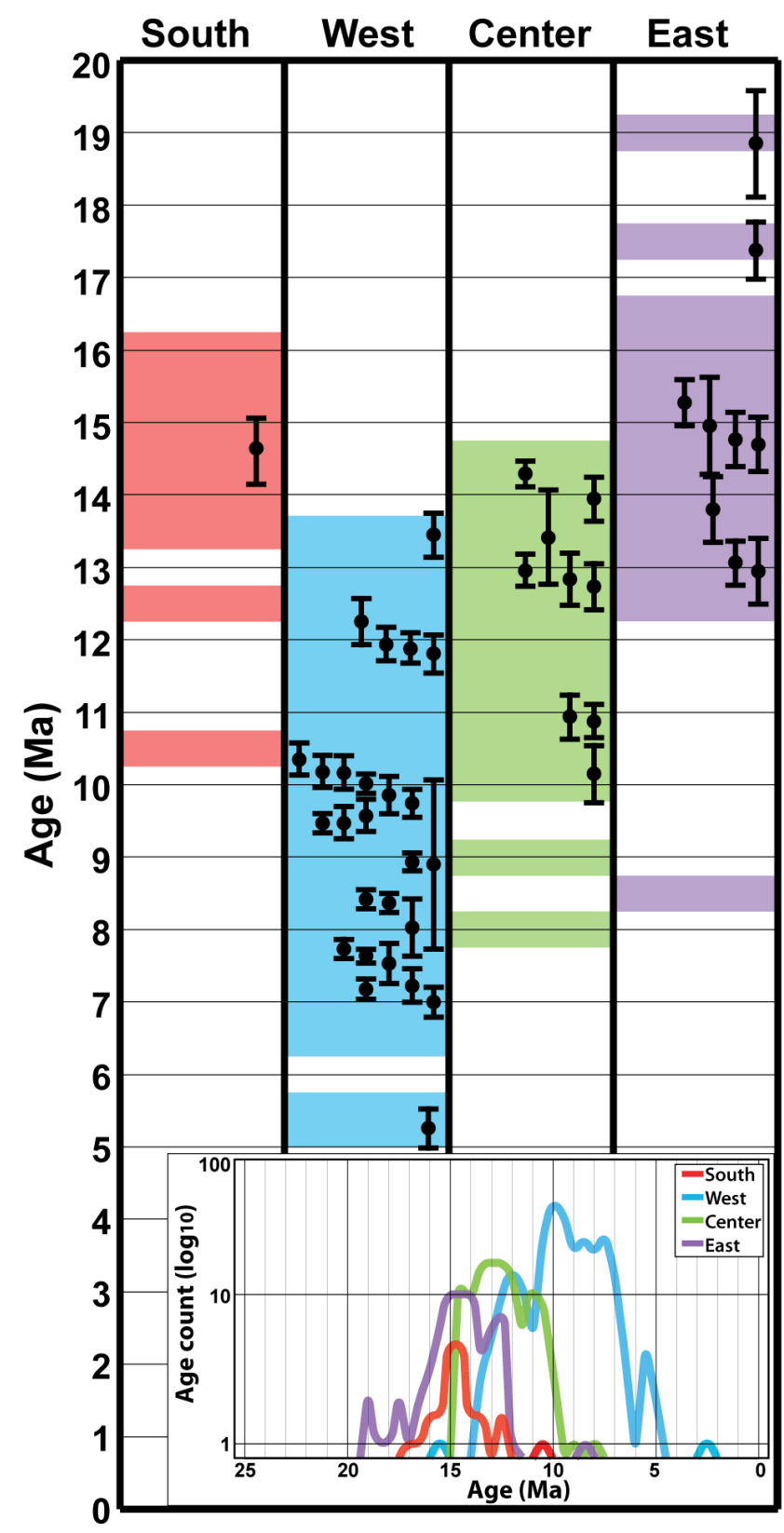

Figure 4. Time diagram combining the overall age recording time from the inset and weighted mean ages of all samples from the Lepontine Dome. The inset shows an age probability density plot representing the data set of each region (Fig. 1) according to the number of ages per $0.5 \mathrm{Myr}$ interval. Black error bars indicate weighted mean ages from this study.

tween being mixing ages or the result of either multiple or continuous (re)crystallization events. These weighted mean ages were only kept if their MSWD did not exceed the $95 \%$ confidence interval for a given number of dates, as recommended by Mahon (1996).

As altered areas may preserve their overall chemical composition but consist of a submicroscopic mix of different phases (e.g., Grand'Homme et al., 2016), and analyses belonging to the same chemical group may show a large age scatter, the finite number of analyses per grain would result in many individual ages being discarded for these areas. Accordingly, events may, especially in larger grains, not be recognized if looking at the well-defined weighted mean ages only. To avoid this, the entire data set of each region was plotted according to the number of ages per $0.5 \mathrm{Myr}$ interval to identify age clusters across the grains of a given region (Fig. 4, inset). Identified deformation stages for which ages were obtained were then combined with the weighted average ages to visualize distinct events or phases of tectonic activity (Fig. 4). As can be seen, some phases of age recording visible in the overall age record were not identified through weighted mean ages alone. For the interpretation of the data, weighted mean ages are preferable to pinpoint deformation events. However, at least the beginning and end of the age record within a sample must have a geological significance since their recording must have been triggered by tectonic activity, even if one assumes all ages in between to be simply mixing ages. Accordingly, weighted mean ages are in the following generally discussed as precise ages, while spot ages are treated as approximate ages.

\section{Results}

The ion-probe measurement data set is given in the data table in the Supplement and can be found in the PANGAEA database (https://doi.org/10.1594/PANGAEA.898689). Only those few measurements that did not yield an age were discarded during the initial data reduction (their positions are included in Fig. 5). The age data of the individual samples and the whole data set cover a large range of ca. $16 \mathrm{Myr}$, between $\sim 19$ and $2.7 \mathrm{Ma}$. Individual grains record ages over a lifetime of 2 to $7.5 \mathrm{Myr}$. An overview over the individual age ranges and the weighted mean domain ages that could be calculated for the individual samples is shown in Table 2 . Figure 5 shows the measurement positions, an age plot, and a chemical plot for each sample.

Sample GRAESER 4 (Appendix Fig. A1; Supplement table) is a grain (co-type) from the monazite-(Nd) type locality (Graeser and Schwander, 1987). Due to very low Th contents, only two spots yielded ages of $11.88 \pm 0.47$ and $12.25 \pm 0.51 \mathrm{Ma}$, clearly indicating that the monazite- $(\mathrm{Nd})$ crystallized coevally with monazite-(Ce).

Typical for hydrothermal cleft and fissure monazite, the contents of Th and $\mathrm{U}$ are generally relatively low compared to monazite from other geological environments (Supplement table; Janots et al., 2012). Th contents mostly range from 5000 to $60000 \mathrm{ppm}$, with (parts of) individual samples considerably lower (down to $1000 \mathrm{ppm}$ ) or higher (up to $110000 \mathrm{ppm}$ ), while $\mathrm{U}$ contents are below $1000 \mathrm{ppm}$ (only KLEM 3 up to $3300 \mathrm{ppm}$ ). This results in very high Th/U ratios of up to 792. Lead contents show a spread from a few up to several hundred ppm, with common $\mathrm{Pb}$ contents for 
the most part considerably below $10 \%$. A number of measurements in GRAESER 3 and TAMB 1 show very high common $\mathrm{Pb}$ contents, largely above $70 \%$, with a maximum of $99 \%$. While generally increasing the uncertainty in the age data, this is insignificant for the age data presented here as these show no significant age difference between spots with high or low common $\mathrm{Pb}$ contents (except for sample GRAESER 3). With the exception of samples BLAS 1 and GRAESER 3, all sample grains show at least some alteration features (irregular, wavy, or unclear zonation, porosity; see also Sect. 3.1) and can roughly be divided into five partly overlapping groups on the basis of their appearance in BSE images (Fig. 5; for an introduction into this, see Catlos, 2013).

(1) Sector-(like) zonation:

- DUTH 6 shows some signs of alteration or replacement and complex zonation in the inner part of the grain.

- GRAESER 3 shows no clear signs of alteration but an extreme zonation in both Th $(\sim 1800$ $113000 \mathrm{ppm})$ and $\mathrm{U}(\sim 10-680 \mathrm{ppm})$ contents according to visible zonation and elevated $(>10 \%)$ to extreme $(65 \%-99 \%)$ common $\mathrm{Pb}$ contents. The ages derived from the low-Th measurements should be treated with caution, as they show a greater spread at higher error than the other measurements.

- VANI 4 shows in places strong signs of alteration like cross-cutting and rounded zonation.

- VANI 5 displays in places only weak zonation with sometimes strong alteration signs. Thorium contents are relatively low (1600-10 $800 \mathrm{ppm}$ ) and common $\mathrm{Pb}$ contents elevated but mostly below $20 \%$.

- VALS, by far the largest analyzed grain, shows in places only weak zonation with sometimes strong alteration features. Thorium contents are low (> $3500 \mathrm{ppm}$ ) with only an overgrowth rim showing higher contents (up to $12300 \mathrm{ppm}$ ). Common $\mathrm{Pb}$ contents are elevated but remain below $25 \%$.

(2) Sector-(like) plus oscillatory or ring zonation:

- BLAS 1 shows no visible signs of alteration, but the interior part of the crystal gives younger ages than the outer part, meaning that (incomplete) alteration likely happened along microcracks.

- DORU 1 has strong zonation with only minor signs of alteration.

- KLEM 1 shows signs of alteration, and the zonation is diffuse in places like the center and part of the rim.
- SCHIESS 1 shows many cracks and in parts strong alteration signs like porosity, and the primary zonation is cut in places.

(3) Clear distinction between primary and altered zones:

- BETT 11 is the only sample that shows no (primary) zonation, but it shows altered areas around holes and along rims.

- VANI 6 displays oscillatory-complex zonation, with clearly discernible altered grain parts around pores and along rims.

- LUCO 1 is largely featureless in the lighter parts of the BSE image, with right and interior parts showing an intricate secondary zonation pattern.

(4) Weak zonation with minor alteration features:

- DUTH 2 displays only weak remnants of sectorlike zonation.

- KLEM 3 shows weak remnants of oscillatory zonation that is cut and transitions in places into a diffuse pattern.

- SALZ 2 shows remains of sector-like combined with complex zonation.

(5) Weak zonation with strong alteration features:

- DORU 2 displays remnants of oscillatory zonation.

- DUTH 3 has partly preserved oscillatory zonation with large parts of the grain having only very weak zonation.

- GRAESER 1 shows remains of sector combined with oscillatory zonation but strong zonation in the altered parts of the crystal.

- GRAESER 4 (see Appendix) shows remnants of sector zonation and has very low Th contents of just below $1100 \mathrm{ppm}$ and elevated common $\mathrm{Pb}$ contents below $20 \%$.

- KLEM 2 has a diffuse internal structure with only weakly preserved zonation and elevated common $\mathrm{Pb}$ contents that remain below $21 \%$.

- TAMB 1 has a weakly pronounced patchy zonation, with little growth or alteration patterns apart from porosity and cracks visible within the grain. Thorium contents are low (>3300 ppm). While most of the measurements have common $\mathrm{Pb}$ contents of $>5 \%$, five measurements show very high contents of $72 \%-96 \%$, but despite this the dates appear undisturbed. 

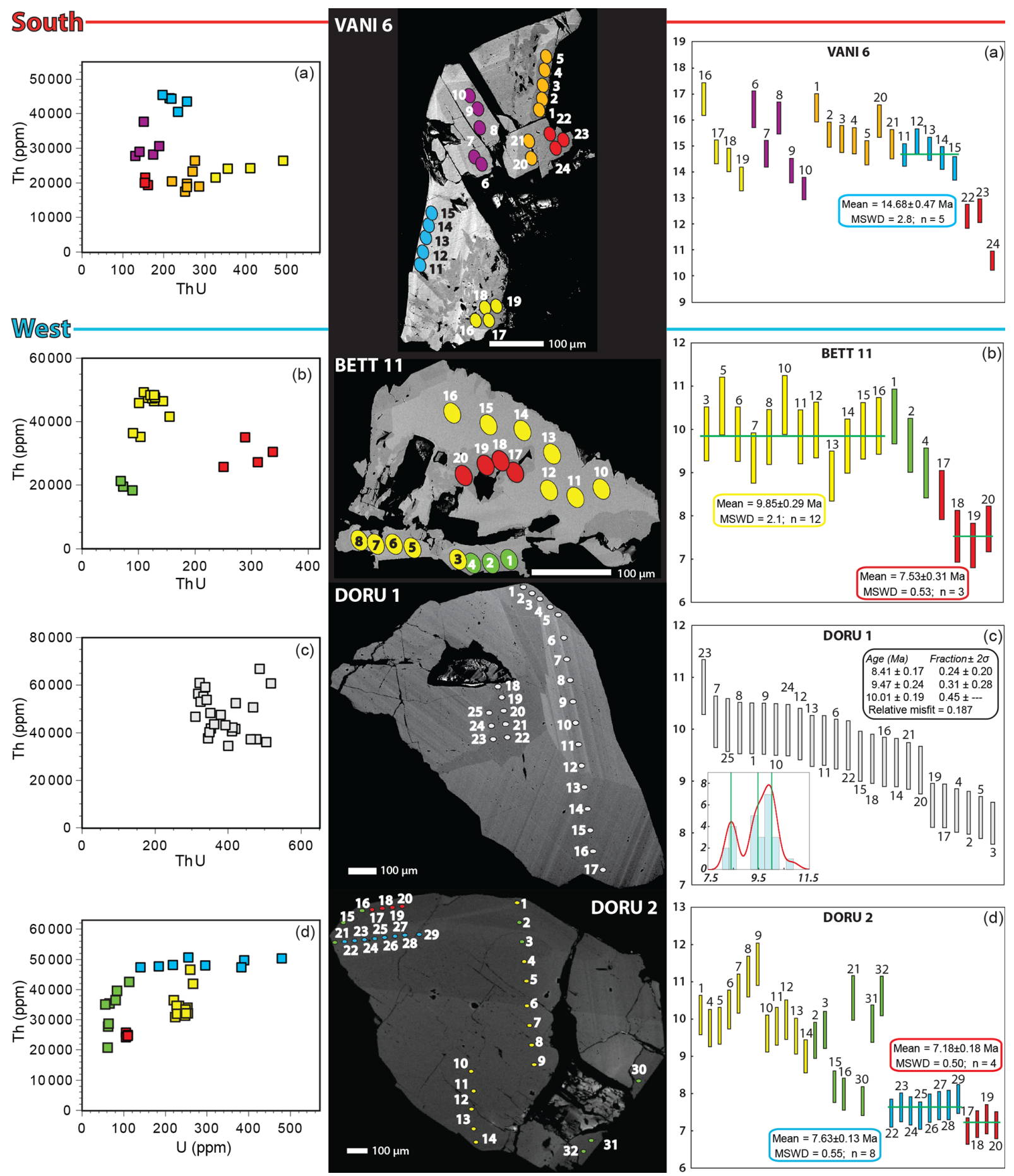

Figure 5. 

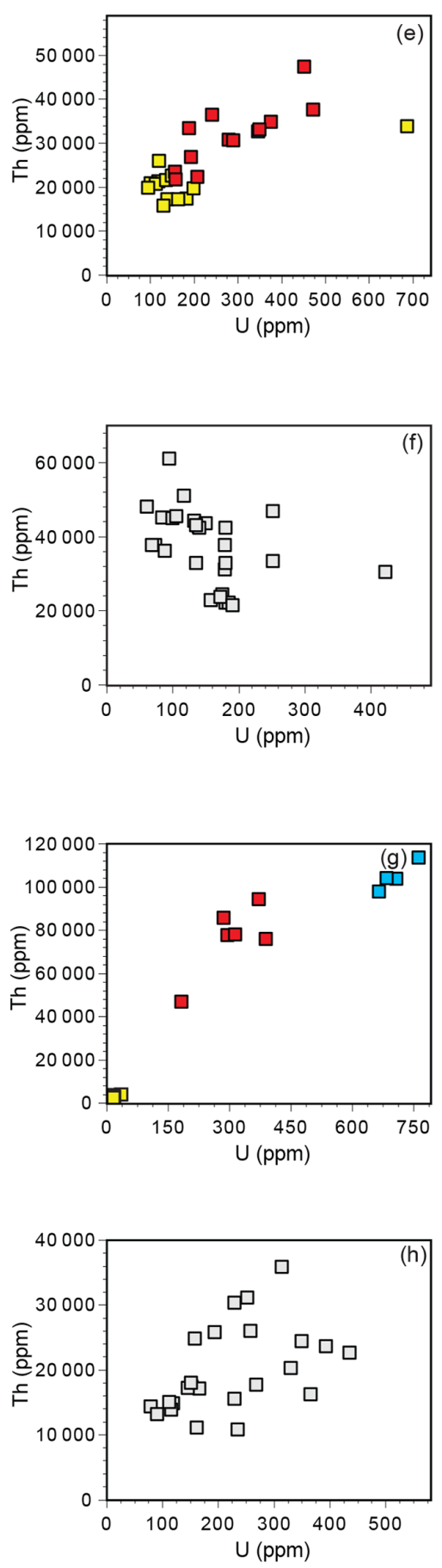
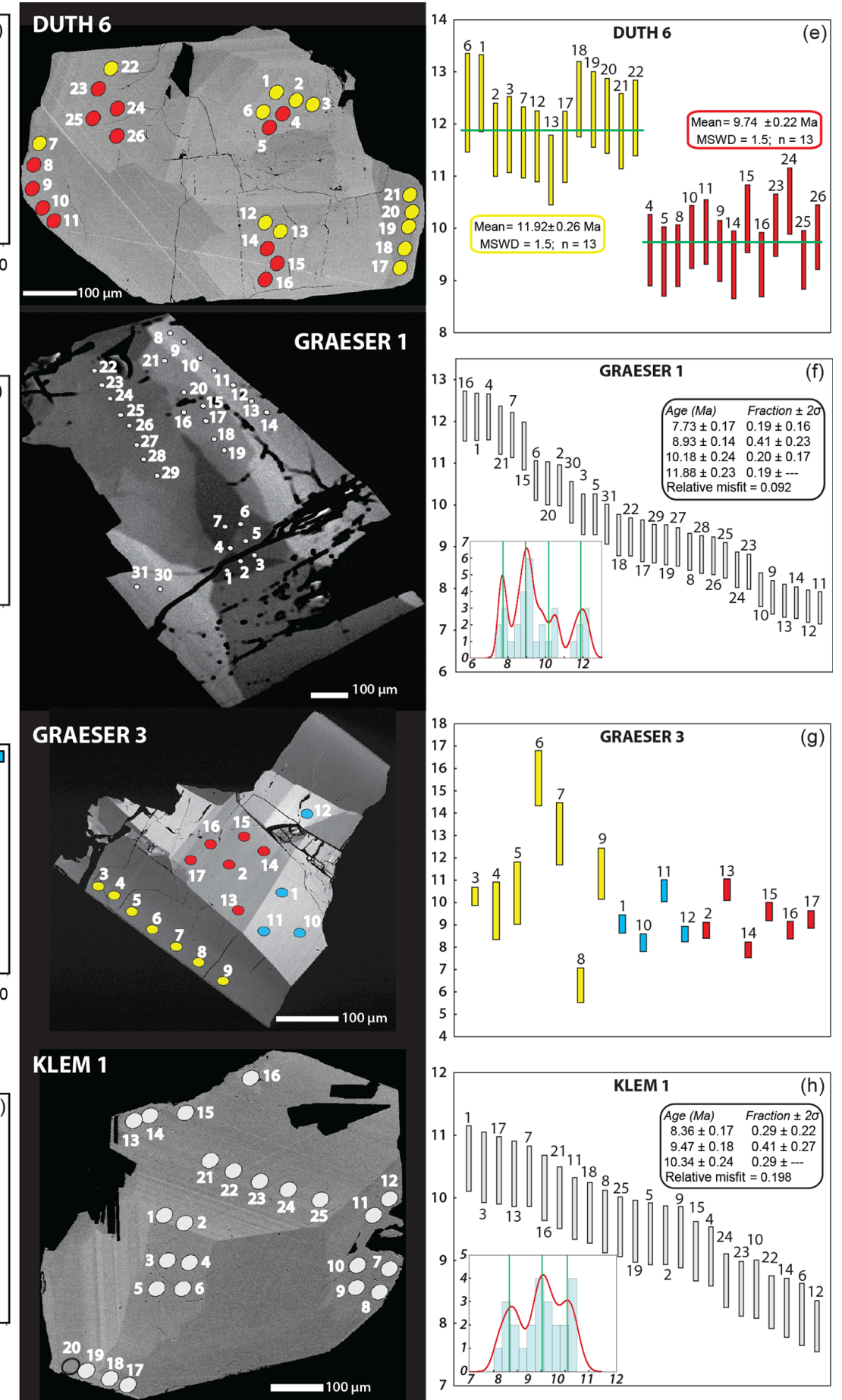

Figure 5. 

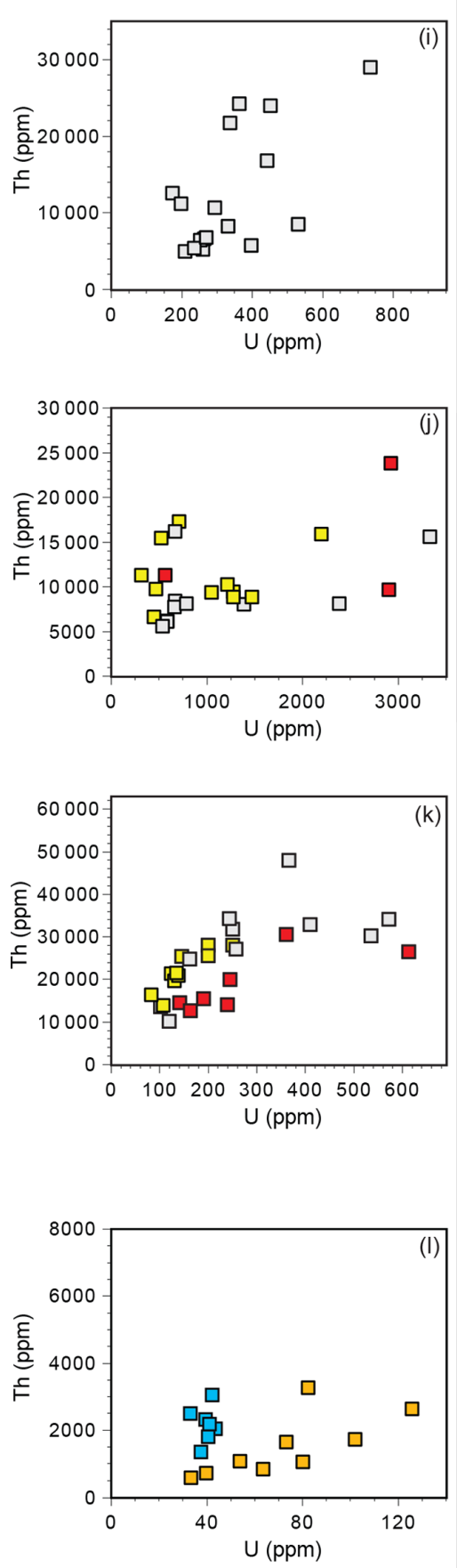
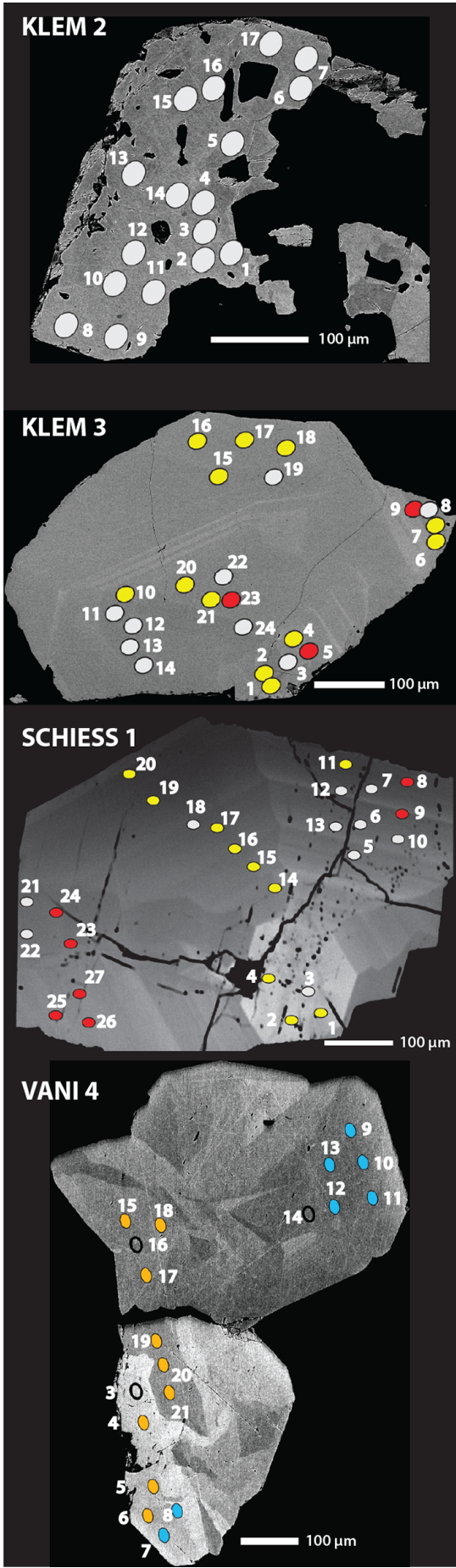
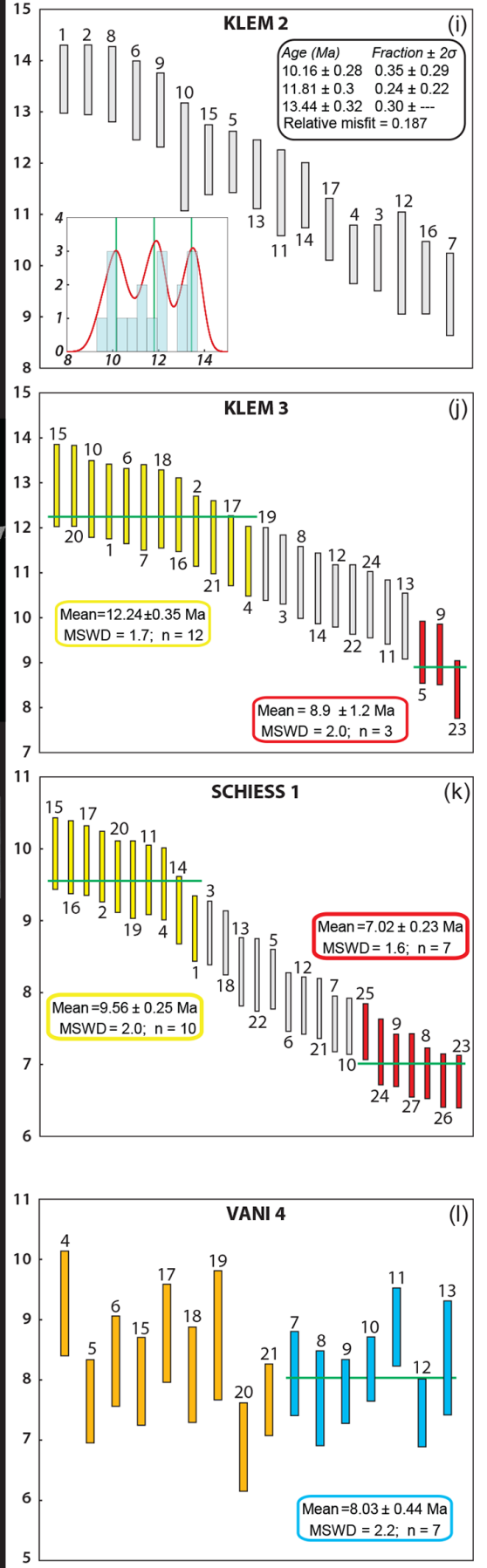

Figure 5. 

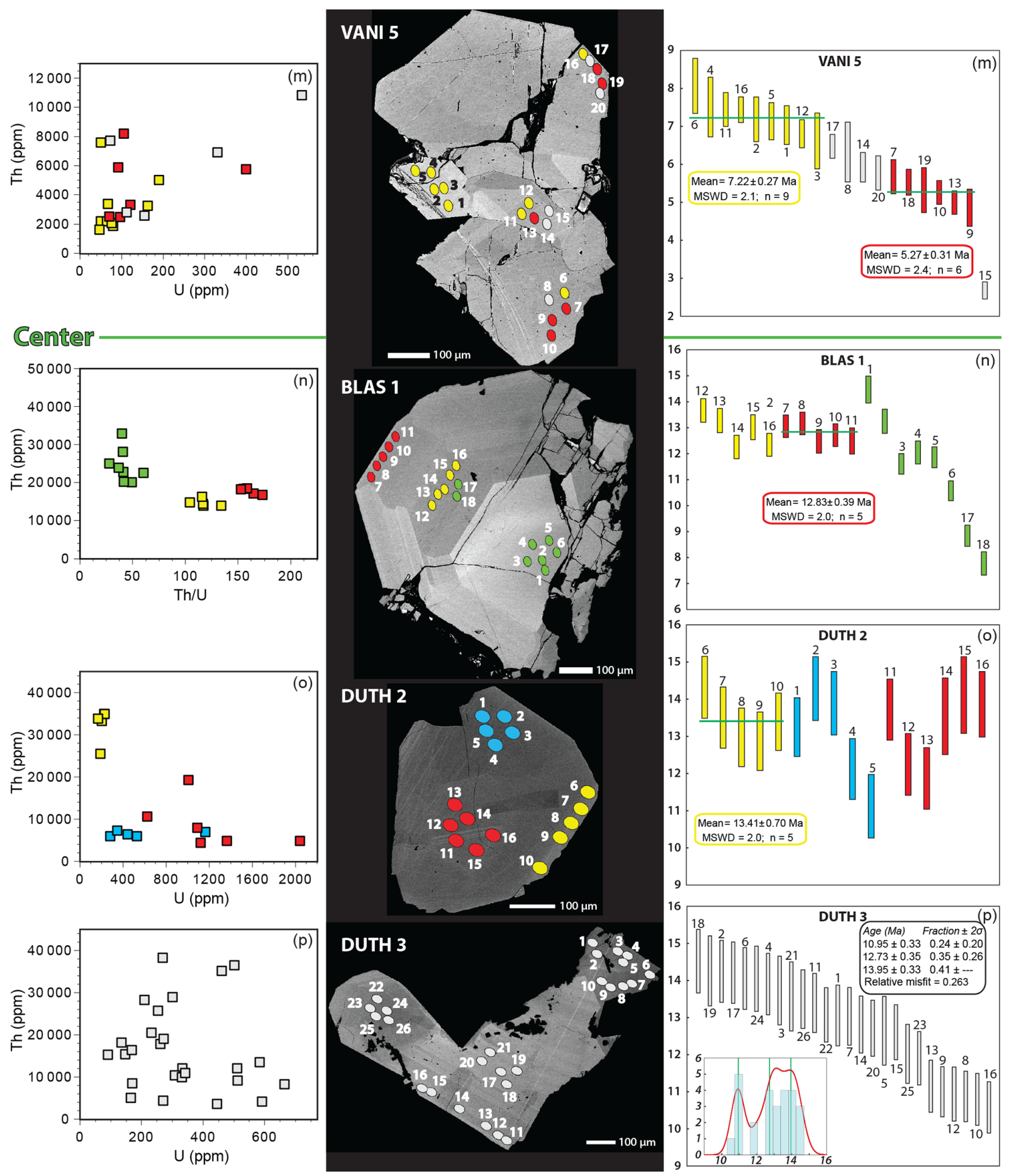

Figure 5. 

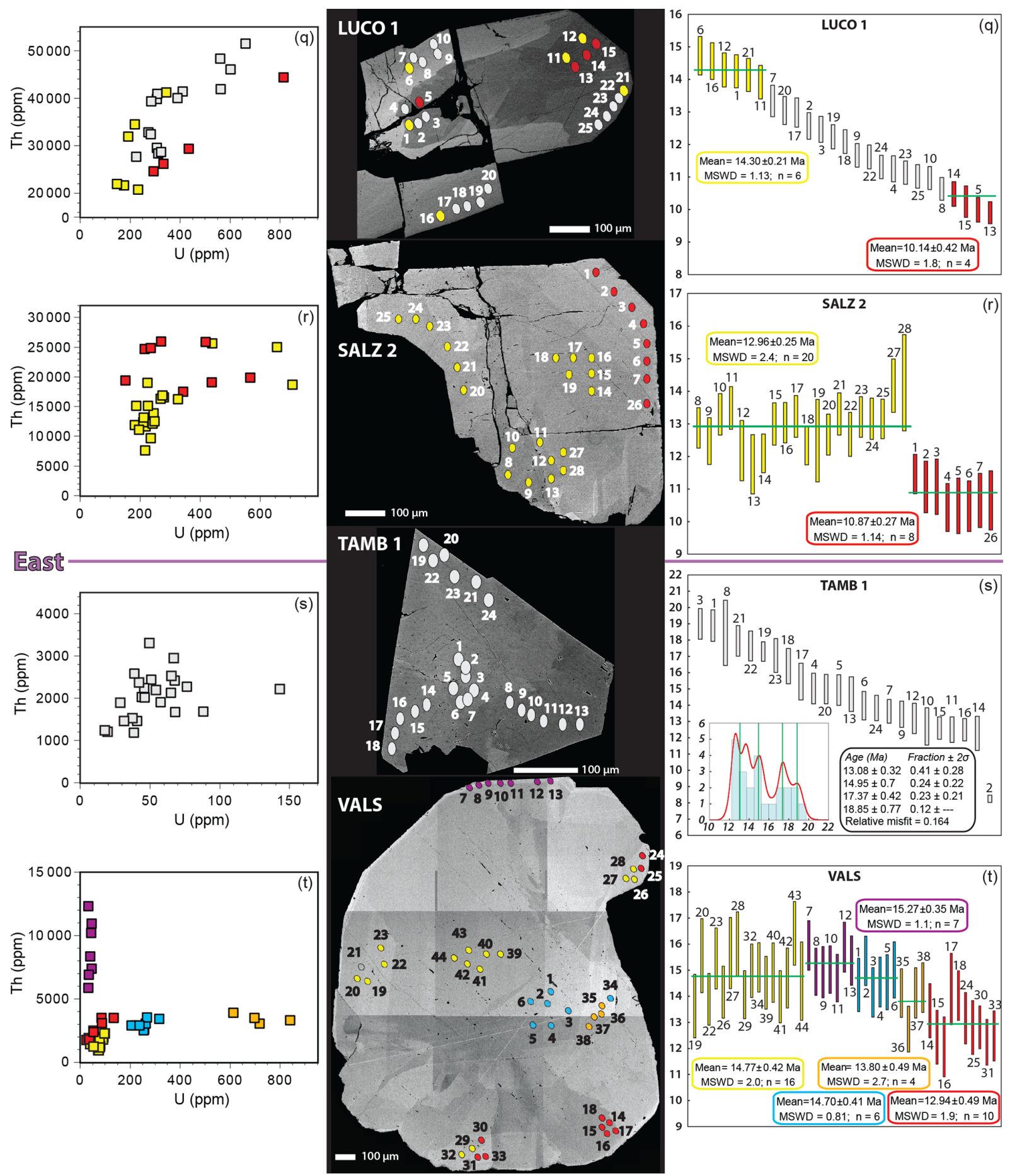

Figure 5. Visualization by sample of all SIMS analyses conducted for this study. Chemical plots that best show the different groups within a sample (left), BSE images (center) with colored ovals representing analysis spots being to scale, and age diagrams (right) show ${ }^{208} \mathrm{~Pb} /{ }^{232} \mathrm{Th}$ ages. Gray ovals were not included in any of the groups. 


\section{Discussion}

\subsection{Hydrothermal monazite-(Ce) ages compared to thermochronometry during cooling}

Hydrothermal monazite-(Ce) crystallization and alteration typically occur in a fluid temperature window of ca. $350{ }^{\circ} \mathrm{C}$ down to at least $200^{\circ} \mathrm{C}$ (Gnos et al., 2015; Bergemann et al., 2017,2018 ) but probably considerably below as is, for example, visible in Fig. 6. This is by its nature independent of the local cooling rate, since for the monazite-(Ce) crystallization the temperature window and fluid chemistry instead of the cooling speed is the critical factor. In most areas the oldest recorded hydrothermal monazite-(Ce) ages are predated by ${ }^{40} \mathrm{Ar} /{ }^{39} \mathrm{Ar}$ white mica cooling ages, and they are slightly younger than or equal to zircon fission-track (ZFT) ages (Fig. 6, although here $\mathrm{K}-\mathrm{Ar}$ ages instead of ${ }^{40} \mathrm{Ar} /{ }^{39} \mathrm{Ar}$ ages are shown; Gnos et al., 2015; Grand'Homme et al., 2016; Bergemann et al., 2017, 2019b; Ricchi et al., 2019). This sequence is also found in most parts of the Lepontine Dome as shown for samples located in the vicinity of the NE-SW cross section Fig. 6.

A comparison of monazite-(Ce) crystallization ages with ages obtained with thermochronometers, whose closure temperatures depend on the cooling rate, seems to allow for the identification of areas experiencing low cooling rates at the time of hydrothermal monazite growth. In such cases, monazite has a larger time window to record tectonic activity, and ${ }^{40} \mathrm{Ar} /{ }^{39} \mathrm{Ar}$ white mica ages coincide with the beginning of the monazite-(Ce) age record, whereas ZFT ages coincide with or even postdate the youngest found monazite-(Ce) ages. This is the case in the central region of the study area, where the youngest white mica cooling ages of $15.1 \pm 0.70$ to $16.30 \pm 0.23 \mathrm{Ma}$ (Allaz et al., 2011) located west of sample DUTH 2 and south of sample LUCO 1 (Fig. 1) coincide with the earliest monazite-(Ce) crystallization dated at ca. 14.3 to 14.7 Ma, and ZFT ages of 9.7 $\pm 0.5 \mathrm{Ma}$ (Janots et al., 2009) coincide with the late phase of monazite-(Ce) age recording around $10 \mathrm{Ma}$. Also in the vicinity of sample VANI 6 south of the Rhone-Simplon Fault (RSF) (Fig. 1), the ZFT ages ranging from $12.0 \pm 2.6$ to $7.1 \pm 1.6 \mathrm{Ma}$ (Keller et al., 2005) overlap with the youngest monazite-(Ce) spot ages of around 12.5 to $10.6 \mathrm{Ma}$. There are no ${ }^{40} \mathrm{Ar} /{ }^{39} \mathrm{Ar}$ white mica ages in the direct vicinity of VANI 6. However, the sample is located in an area that does not show the large jump in cooling ages (Fig. 6) found across the rest of the brittle Rhone-Simplon Fault bordering the Lepontine Dome to the west (Keller et al., 2005; Campani et al., 2010). A similar age pattern was also found outside the study area, in the Eastern Alps in Austria, in an area affected by Cretaceous Eo-Alpine Barrow-type metamorphism (Bergemann et al., 2018). There, primary monazite-(Ce) mean ages of $90.6 \pm 1.3$ to $89.2 \pm 1.8 \mathrm{Ma}$ coincide with ${ }^{40} \mathrm{Ar} /{ }^{39} \mathrm{Ar}$ white mica ages of $88.4 \pm 0.4$ to $84.3 \pm 0.7 \mathrm{Ma}$ (Dallmeyer et al., 1996), and the youngest monazite spot ages of around $70 \mathrm{Ma}$ coincide with
ZFT ages that show a considerable spread of ca. 70-50 Ma (Kurz et al., 2011; van Gelder et al., 2015). The three areas have in common that exhumation or cooling rates were low during the time of hydrothermal monazite-(Ce) crystallization (e.g., Fügenschuh et al., 2000; Steck et al., 2013) compared to other parts of the Alps from which hydrothermal monazite-(Ce) was dated (Gnos et al., 2015; Bergemann et al., 2017, 2019b; Ricchi et al., 2019).

A possible explanation for this difference in age relations is that, due to the slow cooling rates, the Ar isotope system closure and the end of fission-track annealing would have occurred at the lower end of their respective closure temperature windows since the systems had time to equilibrate even at lower temperatures. Monazite-(Ce) crystallization, on the other hand, presumably occurred during its ca. $350{ }^{\circ} \mathrm{C}$ down to or likely below $200^{\circ} \mathrm{C}$ temperature window (Gnos et al., 2015; Bergemann et al., 2017, 2018). This means that during ongoing tectonic activity the coincidence of ${ }^{40} \mathrm{Ar} /{ }^{39} \mathrm{Ar}$ white mica ages with the beginning of monazite-(Ce) crystallization and ZFT ages overlapping with the latest monazite-(Ce) crystallization may be an indication of slow exhumation or cooling rates. Since monazite-(Ce) (re)precipitation depends on a disequilibration of the fissure or cleft system, a lack of this relation does, on the other hand, not exclude low exhumation rates for an area. This could, for example, be the case if initial monazite-(Ce) formation did not occur at the upper end of its formation window or if the analyzed monazite comes from a younger cleft generation that formed after a change in deformation style from, for example, thrusting to strike-slip formation (see Bergemann et al., 2017; Ricchi et al., 2019).

\subsection{Monazite-(Ce) ages and late Lepontine Dome evolution}

Hydrothermal cleft monazite-(Ce) crystallization and dissolution-reprecipitation varied in space and time in the study region as it passed through the monazite-(Ce) crystallization recording window. The growth duration recorded by the spot age range within individual monazite-(Ce) crystals spans from 2.5 Ma to $7 \mathrm{Myr}$ (Table 2, Fig. 5), with the total spot age range of all grains covering the time from ca. 19 to $2.7 \mathrm{Ma}$. The following description gives an overview over the spatial distribution of the monazite-(Ce) age record visible in Fig. 7, and it is followed by a contextualization within the area.

The monazite-(Ce) age record starts in the eastern region (Fig. 1) of the study area at the edges of the Lepontine Dome (Fig. 7a), with the earliest ages around $19 \mathrm{Ma}$ (sample TAMB 1; Figs. 4, 5s), slightly postdated by sample VALS somewhat to the north of TAMB 1 at $\sim 16.5 \mathrm{Ma}$ (Fig. 5t). As it continues in the east, the age record starts in the central region (Fig. 1) around 14.7-14.3 Ma. This parallel monazite-(Ce) age record for the central and eastern regions continues until ca. 12.5 Ma after which it ends in the 


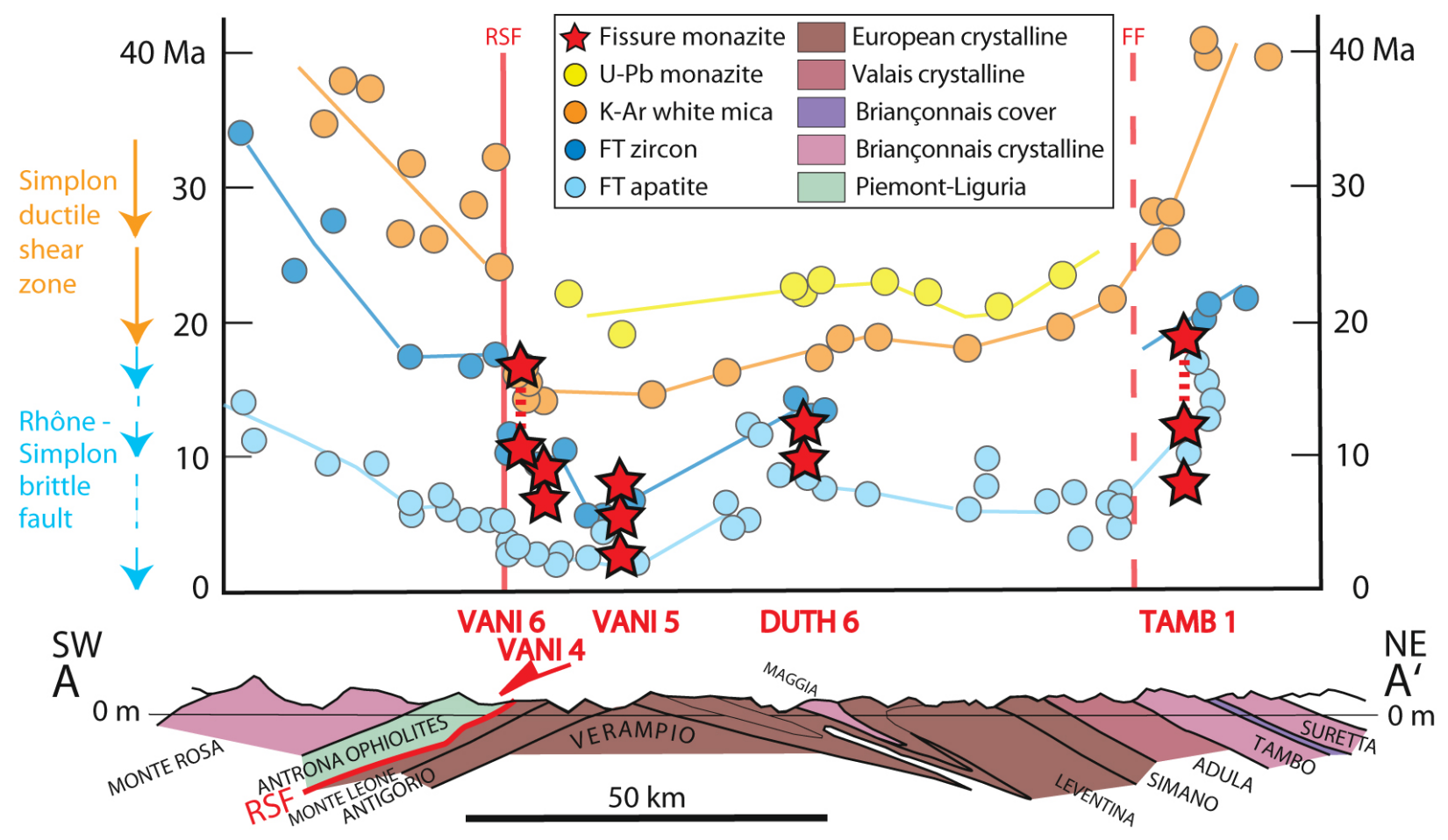

Figure 6. Figure modified from Steck et al. (2013), with cooling ages compiled by Steck and Hunziker (1994), and completed with data from Keller et al. (2005), Rahn (2005), Elfert et al. (2013) and Boston et al. (2017). Cleft monazite crystallization ages of samples from this study, located in the vicinity of the cross section (Figs. 1,2), are shown for comparison. The red lines mark the Rhone-Simplon Fault (RSF) and Forcola Fault (FF, located south of the cross section). Sample VANI 6 is projected into the profile from some distance and into the foot wall of the RSF where cooling ages are similar to those around the sample location of VANI 6. Note that rock-forming monazite dates peak metamorphic conditions considerably higher than the (re)crystallization temperature of the hydrothermal cleft and fissure monazite-(Ce) variety.

east, with the exception of an isolated spot age of $\sim 8.3 \mathrm{Ma}$ (TAMB 1). The western area (Fig. 1) has a more heterogeneous age record with the oldest ages being diachronous within the area from east to west or southwest (Fig. 7b-e). The oldest ages are around 13.6 Ma (KLEM 2) with the area in which ages are recorded progressively spreading west; until ca. $10 \mathrm{Ma}$, most samples from the western region record ages. The age record ends first in the central region and then the easternmost western region at ca. $9.5 \mathrm{Ma}$, except a spot age in the center of 7.8 Ma (BLAS 1). The record continues in most of the western region (Fig. 7e) until it becomes progressively more localized by $\sim 7.5 \mathrm{Ma}$ towards the west and the vicinity of the Rhone-Simplon Fault system (Fig. 7f). The youngest widely recorded monazite-(Ce) age group for this area dates to around $7 \mathrm{Ma}$ (Fig. 7f), and only one sample (VANI 5) records ages down to around $5 \mathrm{Ma}$, with a single spot age of $\sim 2.7 \mathrm{Ma}$. The southern region (Fig. 1) at the SW edge of the Lepontine Dome, separated from the western region by the Rhone-Simplon Fault, shows a similar age range as the eastern region. As in the east, the monazite-(Ce) age record starts early at ca. $16.8 \mathrm{Ma}$ and continues somewhat further down to around $10.6 \mathrm{Ma}$ (Fig. 5a-d).
Overall, the monazite-(Ce) chronological record shows a clear east-west trend without large age jumps within the Lepontine Dome. The record starts in the eastern (and southern) parts of the study area, with the activity then moving through the central to the western area, where it progressively concentrates on the large fault systems in the west of the Lepontine Dome.

The earliest monazite-(Ce) ages, found in the eastern area (TAMB 1; Fig. 1), fall into two groups, with mean ages at $18.85 \pm 0.77$ and $17.37 \pm 0.42 \mathrm{Ma}$ (Fig. 4, Table 2), during which time the area around TAMB 1 experienced a time of rapid exhumation and cooling (Steck and Hunziker, 1994). The nearby Forcola Fault (Fig. 1) was estimated to have been active sometime around 25-18 Ma on the basis of $\mathrm{Rb}-$ $\mathrm{Sr}$ and K-Ar cooling ages (Meyre et al., 1998). In this context, the monazite-(Ce) ages would date the final deformation phases of such normal faults as the Forcola Fault, which shows an age jump in cooling ages similar to that of the Rhone-Simplon Fault but in this case more pronounced for the low-temperature thermochronometers (Fig. 6). Monazite(Ce) spot ages down to $\sim 8.3 \mathrm{Ma}$ (Fig. $5 \mathrm{~s}$, Table 2 ) in conjunction with this age jump suggest that these faults, and possibly the Forcola Fault itself, may have been active far 


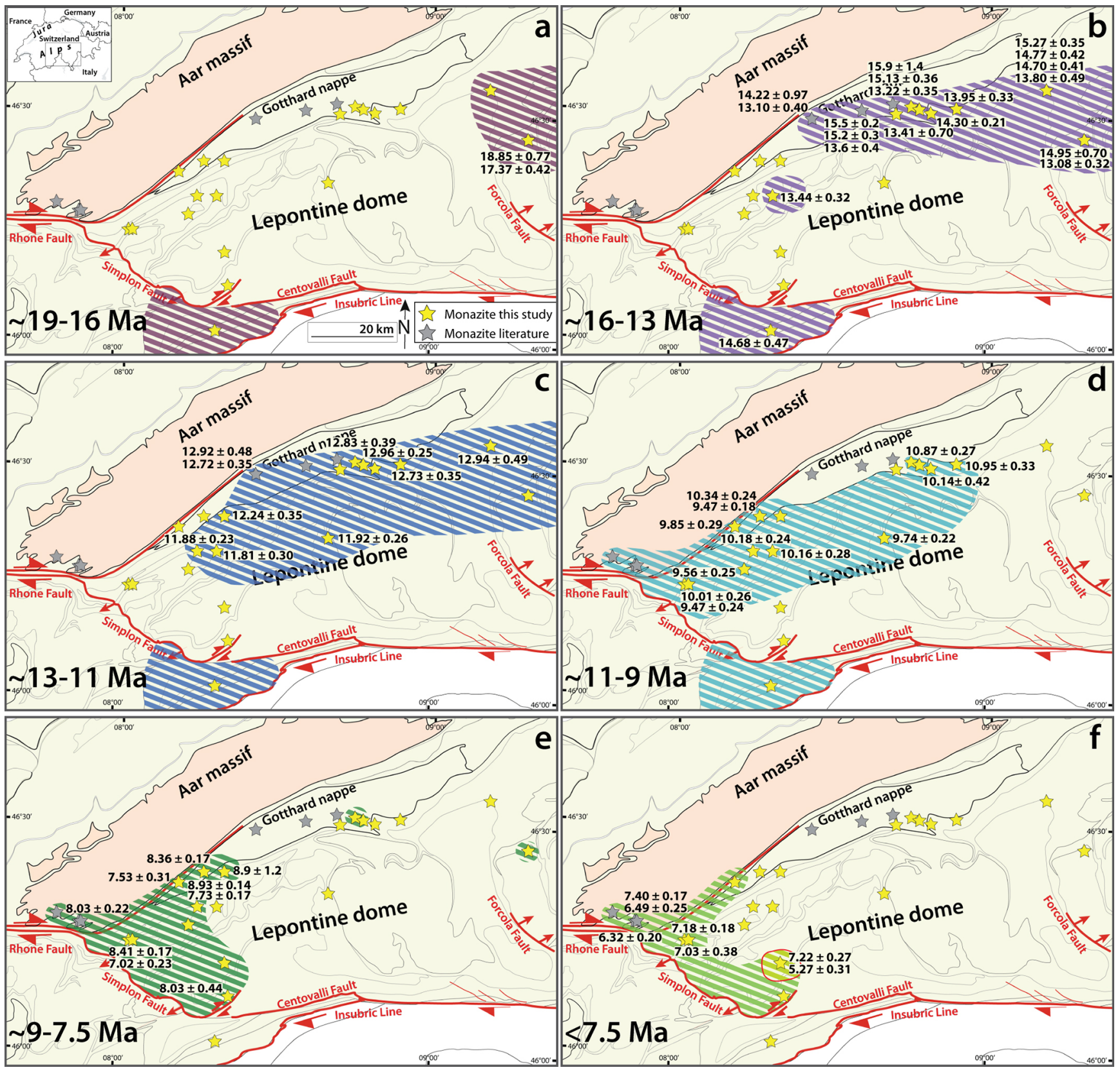

Figure 7. Overview maps of the study area modified from Steck et al. (2013) and Schmid et al. (2004) showing the relevant monazite-(Ce) spot and mean age record over time and space. Note the shift over time from the southern and eastern regions of the Lepontine Dome to the central and western areas and finally to the areas close to the shear zones bounding its western limit. Mean ages, quoted near the stars representing the corresponding sample locations, indicate individual tectonic events that could be identified for a grain. Ages are ordered into six time intervals. Published hydrothermal monazite-(Ce) locations (gray stars) of the areas adjacent to the Lepontine Dome are from Janots et al. (2012), Berger et al. (2013), and Ricchi et al. (2019).

longer than until $18 \mathrm{Ma}$. The youngest ages even postdate apatite fission-track ages (AFT) of 16.9 to $9.9 \mathrm{Ma}$ (Hunziker et al., 1992; Rahn, 2005; Fig. 6). This is unusual and may have been facilitated by the late circulation of hot fluids during renewed deformation. Something similar could be shown for hydrothermal monazite-(Ce) of the Lauzière and Mont
Blanc massifs (Janots et al., 2019; Bergemann et al., 2019b). North of TAMB 1, the age record of sample VALS starts slightly later at $\sim 16.5 \mathrm{Ma}$ and then mirrors that of TAMB 1 (Fig. 5s, t).

In the central area close to the sample locations, temperatures were still prograde up until the time of 19-18 Ma at 
$450-430{ }^{\circ} \mathrm{C}$ (Janots et al., 2009) as deduced from allanite dating. After this time, temperature conditions must have decreased due to exhumation, as the hydrothermal monazite(Ce) age record started after around 16-15 Ma in the central and southern Gotthard Nappe (this study; Ricchi et al., 2019) and eastern Lepontine Dome (Fig. 7b) and continued to later than $\sim 13 \mathrm{Ma}$ (Fig. 7c). After this time, the monazite-(Ce) age record receded from the eastern region, which cooled below $180^{\circ} \mathrm{C}$ around $12 \mathrm{Ma}$ (e.g., Price et al., 2018, zircon $\mathrm{U} / \mathrm{Th}-\mathrm{He}$ ), as well as the Gotthard Nappe, moving west- and southwards into the Lepontine Dome (Fig. 7d). This would date the decoupling of the Gotthard Nappe, which experienced a rapid exhumation due to steepening during backfolding (Wiederkehr et al., 2009; Ricchi et al., 2019), from the Lepontine Dome to ca. 13-12 Ma, as the samples of the central area in the Lepontine Dome show a continued widespread age record down until $\sim 9 \mathrm{Ma}$ (Fig. 7d). During this time interval (Fig. 7c), primary monazite-(Ce) crystallized also along the other parts of the extended RhoneSimplon Fault system (Grand'Homme et al., 2016; Bergemann et al., 2017, 2019b; Ricchi et al., 2019). There, it dates in some areas a change in deformational style, from thrusting or transtensional movements to pure strike-slip deformation, through the formation of a new cleft generation with a different orientation associated with strong hydrothermal fluid activity (Bergemann et al., 2017, 2019b; Janots et al., 2019). Since in the study area clefts are vertical, whether they formed during extension or later strike-slip deformation, such a switch in deformation style cannot be proven. But it might explain the progressive restriction of the monazite(Ce) age record to the vicinity of major fault zones in the western Lepontine Dome (Fig. 7e-f). This excludes the Gotthard Nappe, where sampled clefts are horizontal (see also Ricchi et al., 2019).

Spot ages of $\sim 12-10.5 \mathrm{Ma}$ (Fig. $7 \mathrm{~d}$ ) mark the end of the hydrothermal monazite-(Ce) age record in the hanging wall of the Rhone-Simplon Fault (southern region, Fig. 1), which had continued since $\sim 16.8 \mathrm{Ma}$ (spot age), largely parallel to that in the eastern region (Fig. 7a-d). Comparably old spot ages of $\sim 11.5-10$ Ma mark the beginning of monazite(Ce) crystallization in the foot wall of the Rhone-Simplon Fault (Figs. 1, 7d), which tend to postdate, but are still in close agreement with, zircon fission-track ages (Fig. 6). The often well-constrained weighted mean ages of western region samples (Figs. 4, 5b-d) might suggest a dominance of strong individual tectonic events. With this in mind, weighted mean ages in this area (Fig. 4) may suggest deformation during brittle tectonics along the extended Rhone-Simplon Fault system.

The mean age group around $12 \mathrm{Ma}$, found in the eastern part of the western zone (Figs. 4, 7c), is related to the more strongly exhumed areas with some distance from the Simplon Fault (Haertel et al., 2013), whereas the younger ages are closer to the localized, late Simplon Fault. The $12 \mathrm{Ma}$ age also falls together with the switch in deforma- tional style elsewhere in the Western Alps mentioned above, and it is followed by multiple mean ages from $\sim 10.5$ to $7 \mathrm{Ma}$, with weakly defined clusters around 10.5-9.5 and 8.5$7 \mathrm{Ma}$ (Figs. 4, 7d). The older ages of these age groups are also recorded towards the central Lepontine (sample DUTH 6; Figs. 5e, $7 \mathrm{c}-\mathrm{d}$ ), but after ca. $10 \mathrm{Ma}$ the ages are progressively restricted to the westernmost areas close to the fault zones (Figs. 4, 7e, f). The younger mean ages likely mark events of strong tectonic activity and corroborate evidence of continuing deformation along the Rhone-Simplon Fault (e.g., Zwingmann and Mancktelow, 2004; Campani et al., 2010; Surace et al., 2011). Only one sample in this group (VANI 5; Fig. 7f) yields ages younger than ca. $7 \mathrm{Ma}$, with a weighted mean age of $5.27 \pm 0.31 \mathrm{Ma}$ and a spot age of $\sim$ $2.7 \mathrm{Ma}$ (Fig. 5m). The sample comes from an area where latestage hydrothermal activity occurred (Pettke et al., 1999), and the mean age coincides with ZFT ages of 6.4-5.4 Ma that are younger than those found in most of the region (Keller et al., 2006). This coincidence of ages younger than in the surrounding areas may indicate a localized resetting of the ZFT ages through the hydrothermal activity. The phases of deformation recorded in the western Lepontine Dome are not local, but they seem to have affected much of the extended Rhone-Simplon Fault system in the Western Alps (Berger et al., 2013; Grand'Homme et al., 2016; Bergemann et al., 2017, 2019b; Ricchi et al., 2019).

\section{Summary}

Hydrothermal fissure monazite-(Ce) offers the possibility to date tectonic activity in the brittle domain for extended time periods, as it provides a record of the shifting tectonic activity within the Lepontine Dome likely associated with the regional exhumation and shear zone history. The fluid and likely often also host rock temperature range of roughly $350{ }^{\circ} \mathrm{C}$ to at least $200^{\circ} \mathrm{C}$, as indicated by previous studies, likely extends to significantly lower temperatures as suggested by a comparison with thermochronometers. This comparison between hydrothermal monazite-(Ce) samples from different parts of the Lepontine Dome area and the Eastern Alps with thermochronometric data suggests that hydrothermal monazite-(Ce) dating might help with identifying areas of slow exhumation or cooling rates during ongoing tectonic activity. The ${ }^{232} \mathrm{Th}-{ }^{208} \mathrm{~Pb}$ monazite-(Ce) crystallization data record prolonged hydrothermal activity during tectonics between $\sim 19$ and $2.7 \mathrm{Ma}$ and thereby contributed to the understanding of the tectonic evolution of the Central Alps. Overall, the monazite-(Ce) age record reveals a relatively smooth east-west age trend within the Lepontine Dome. The record starts in the eastern (and southern) parts of the study area, with the recorded activity then moving through the central to the western area, where it progressively concentrates on the large fault systems of the western Lepontine Dome. 
Appendix A

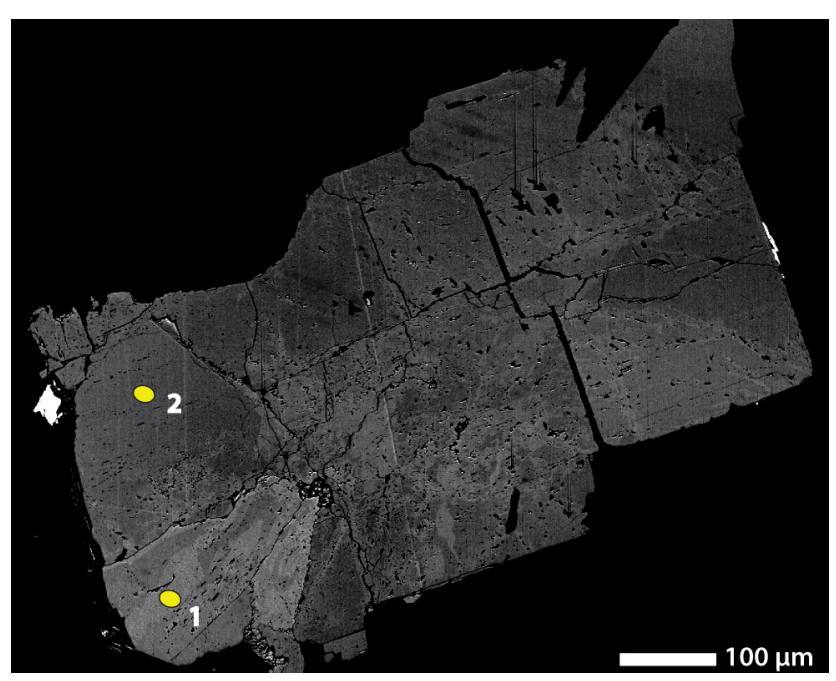

Figure A1. Backscatter electron image of monazite-(Nd) co-type material sample GRAESER 4 with the ovals representing the two measurement spots that yielded a $\mathrm{Th}-\mathrm{Pb}$ age to scale. 
Data availability. The data set given in the Supplement is stored and accessible under https://doi.org/10.1594/PANGAEA.898689 (Bergemann et al., 2019a).

Supplement. The supplement related to this article is available online at: https://doi.org/10.5194/se-11-199-2020-supplement.

Author contributions. EG acquired the sample material. CAB and EJ conducted the $\mathrm{Th}-\mathrm{Pb}$ measurements with the assistance of MJW for analyses and data treatment. EG and $\mathrm{AB}$ advised on the interpretation of the results. $\mathrm{CAB}$ prepared the article with contributions from all co-authors.

Competing interests. The authors declare that they have no conflict of interest.

Acknowledgements. Fraukje Brouwer and Meinert Rahn are thanked for their very helpful and detailed reviews that greatly improved this article. We would also like to thank Bernhard Grasemann and Anna Wenzel for their editorial handling and helpful contact during manuscript revision. Axel Schmitt is thanked for discussions during the revision process. We greatly appreciate the help of Martin Andres, Rudolf Duthaler, Michael Flepp, Stefan Graeser, Leo Klemm, Beda Hofmann, Alexandre Salzmann, Francesco Vanini, and Manfred Walter by providing monazite-(Ce) samples for this study.

Financial support. This research has been supported by the Swiss National Science Foundation (grant nos. 200021-143972 and 200020-165513).

Review statement. This paper was edited by Bernhard Grasemann and reviewed by Fraukje Brouwer and Meinert Rahn.

\section{References}

Aleinikoff, J. N., Schenk, W. S., Plank, M. O., Srogi, L., Fanning, C. M., Kamo, L., and Bosbyshell, H.: Deciphering igneous and metamorphic events in high-grade rocks of the Wilmington Complex, Delaware: Morphology, cathodoluminescence and backscattered electron zoning, and SHRIMP U-Pb geochronology of zircon and monazite. Geol. Soc. Am. Bull., 118, 39-64, https://doi.org/10.1130/B25659.1, 2006.

Allaz, J., Engi, M., Berger, A., and Villa, I. M.: The effects of retrograde reactions and of diffusion on ${ }^{40} \mathrm{Ar} /{ }^{39} \mathrm{Ar}$ ages of micas, J. Petrol., 52, 691-716, https://doi.org/10.1093/petrology/egq100, 2011.

Beard, P.: Ueber den Wechsel der Mineralfazies in der Wurzelzone des Penninikums, Schweiz. Miner. Petrog., 38, 363-374, https://doi.org/10.5169/seals-29612, 1958.
Bergemann, C., Gnos, E., Berger, A., Whitehouse, M., Mullis, J., Pettke, T., and Janots, E.: Th-Pb ion probe dating of zoned hydrothermal monazite and its implications for repeated shear zone activity: An example from the central Alps, Switzerland, Tectonics, 36, 671-689, https://doi.org/10.1002/2016TC004407, 2017.

Bergemann, C. A., Gnos, E., Berger, A., Whitehouse, M. J., Mullis, J., Walter, F., and Bojar, H. P.: Constraining longterm fault activity in the brittle domain through in-situ dating of hydrothermal monazite, Terra Nova, 30, 440-446, https://doi.org/10.1111/ter.12360, 2018.

Bergemann, C. A., Gnos, E., Berger, A., Janots, E., and Whitehouse, M. J.: Hydrothermal cleft monazite SIMS Th-Pb age data, central Alps, PANGAEA, https://doi.org/10.1594/PANGAEA.898689, 2019a.

Bergemann, C. A., Gnos, E., and Whitehouse, M. J.: Insights into the tectonic history of the Western Alps through dating of fissure monazite in the Mont Blanc and Aiguilles Rouges massifs, Tectonophysics, 750, 203-212, https://doi.org/10.1016/j.tecto.2018.11.013, 2019b.

Berger, A., Mercolli, I., and Engi, M.: The central Lepontine Alps: notes accompanying tectonic and petrographic map sheet Sopra Ceneri (1 : 100000), Schweiz. Miner. Petrog., 85, 109-146, 2005.

Berger, A., Gnos, E., Janots, E., Whitehouse, M., Soom, M., Frei, R., and Waight, T. E.: Dating brittle tectonic movements with cleft monazite: Fluid-rock interaction and formation of REE minerals, Tectonics, 32, 1-14, https://doi.org/10.1002/tect.20071, 2013.

Boston, K. R., Rubatto, D., Hermann, J., Engi, M., and Amelin, Y.: Geochronology of accessory allanite and monazite in the Barrovian metamorphic sequence of the Central Alps, Switzerland, Lithos, 286-287, 502-518, https://doi.org/10.1016/j.lithos.2017.06.025, 2017.

Budzyn, B., Harlov, D. E., Williams, M. L., and Jercinovic, M. J.: Experimental determination of stability relations between monazite, fluorapatite, allanite, and REE-epidote as a function of pressure, temperature, and fluid composition, Am. Mineral., 96, 1547-1567, https://doi.org/10.2138/am.2011.3741, 2011.

Campani, M., Mancktelow, N., Seward, D., Rolland, Y., Müller, W., and Guerra, I.: Geochronological evidence for continuous exhumation through the ductile-brittle transition along a crustalscale low-angle normal fault: Simplon Fault Zone, central Alps, Tectonics, 29, TC3002, https://doi.org/10.1029/2009TC002582, 2010.

Campani, M., Mancktelow, N., and Courrioux, G.: The 3D interplay between folding and faulting in a syn-orogenic extensional system: the Simplon Fault Zone in the Central Alps (Switzerland and Italy), Swiss J. Geosci., 107, 251-271, https://doi.org/10.2138/am.2013.4336, 2014.

Catlos, E. J.: Generalizations about monazite: Implications for geochronologic studies, Am. Mineral., 98, 819-832, https://doi.org/10.2138/am.2013.4336, 2013.

Cherniak, D. J. and Pyle, J. M.: Th diffusion in monazite, Chem. Geol., 256, 52-61, https://doi.org/10.1016/j.chemgeo.2008.07.024, 2008.

Cherniak, D. J., Watson, E. B., Grove, M., and Harrison, $\mathrm{T}$. $\mathrm{M}$.: $\mathrm{Pb}$ diffusion in monazite: A combined RBS/SIMS study, Geochim. Cosmochim. Ac., 68, 829-840, https://doi.org/10.1016/j.gca.2003.07.012, 2004. 
Dallmeyer, R. D., Neubauer, F., Handler, R., Fritz, H., Müller, W., Pana, D., and Putis, M.: Tectonothermal evolution of the internal Alps and Carpathians: Evidence from ${ }^{40} \mathrm{Ar} /{ }^{39} \mathrm{Ar}$ mineral and whole-rock data, Eclogae Geolog. Helv., 89, 203-227, https://doi.org/10.5169/seals-167900, 1996.

Elfert, S., Reiter, W., and Spiegel, C.: Long-lasting tectonic activities of the Lepontine Dome. New evidence from lowtemperature thermochronology, Tectonophysics, 608, 222-236, https://doi.org/10.1016/j.tecto.2013.09.033, 2013.

Fügenschuh, B., Mancktelow, N. S., and Seward, D.: Cretaceous to Neogene cooling and exhumation history of the Oetztal-Stubai basement complex, eastern Alps: A structural and fission track study, Tectonics, 19, 905-918, https://doi.org/10.1029/2000TC900014, 2000.

Gasquet, D., Bertrand, J.-M., Paquette, J.-L., Lehmann, J., Ratzov, G., De Ascencao Guedes, R., Tiepolo, M., Boullier, A.-M., Scaillet, S., and Nomade, S.: Miocene to Messinian deformation and hydrothermal activity in a preAlpine basement massif of the French western Alps: new $\mathrm{U}-\mathrm{Th}-\mathrm{Pb}$ and Argon ages from the Lauzière massif, Bulletin de la Société Géologique de France, 181, 227-241, https://doi.org/10.2113/gssgfbull.181.3.227, 2010.

Gnos, E., Janots, E., Berger, A., Whitehouse, M., Walter, F., Pettke, T., and Bergemann, C.: Age of cleft monazites in the eastern Tauern Window: constraints on crystallization conditions of hydrothermal monazite, Swiss J. Geoci., 108, 55-74, https://doi.org/10.1007/s00015-015-0178-z, 2015.

Graeser, S. and Schwander, H.: Gasparite-(Ce) and monazite-(Nd): two new minerals to the monazite group from the Alps, Schweizerische Mineralogische und Petrographische Mitteilungen, 67, 103-113, https://doi.org/10.5169/seals-51591, 1987.

Grand'Homme, A., Janots, E., Seydoux-Guillaume, A.-M., Guillaume, D., Bosse, V., and Magnin, V.: Partial resetting of the $\mathrm{U}-\mathrm{Th}-\mathrm{Pb}$ systems in experimentally altered monazite: Nanoscale evidence of incomplete replacement, Geology, 44, 431-434, https://doi.org/10.1130/G37770.1, 2016.

Grand'Homme, A., Janots, E., Seydoux-Guillaume, A.-M., Guillaume, D., Magnin, V., Hövelmann, J., Höschen, C., and Boiron, M. C.: Mass transport and fractionation during monazite alteration by anisotropic replacement, Chem. Geol., 484, 51-68, https://doi.org/10.1016/j.chemgeo.2017.10.008, 2018.

Grosjean, G., Sue, C., and Burkhard, M.: Late Neogene extension in the vicinity of the Simplon fault zone (central Alps, Switzerland), Eclogae Geol. Helv., 97, 33-46, https://doi.org/10.1007/s00015004-1114-9, 2004.

Haertel, M., Herwegh, M., and Pettke, T.: Titanium-in-quartz thermometry on synkinematic quartz veins in a retrograde crustal-scale normal fault zone, Tectonophysics, 608, 468-481, https://doi.org/10.1016/j.tecto.2013.08.042, 2013.

Harrison, T. M., McKeegan, K. D., and LeFort, P.: Detection of inherited monazite in the Manaslu leucogranite by ion microprobe dating: crystallization age and tectonic implications, Earth Planet. Sc. Lett., 133, 271-282, https://doi.org/10.1016/0012821X(95)00091-P, 1995.

Heijboer, T. C.: Origin and pathways of pro- and retrograde fluids, PTt paths and fluid-mineral equilibria from Alpine veins of the Central Alps: Case studies of the Fibbia and Amsteg areas, PhD thesis, University of Basel, Basel, Switzerland, https://doi.org/10.5451/unibas-004552692, 2006.
Herwartz, D., Nagel, T. J., Münker, C., Scherer, E. E., and Froitzheim, N.: Tracing two orogenic cycles in one eclogite sample by Lu-Hf garnet chronometry, Nat. Geosci., 4, 178-183, 2011.

Hunziker, J. C., Desmons, J., and Hurford, A. J.: Thirty-two years of geochronological work in the Central and Western Alps: A review on seven maps, Memoires de Geologie, Lausanne, 1992.

Hurford, A. J.: Cooling and uplift patterns in the Lepontine Alps, south-central Switzerland, and an age of vertical movement on the Insubric fault line, Contrib. Mineral. Petr., 93, 413-427, https://doi.org/10.1007/BF00374424, 1986.

Janots, E., Engi, M., Rubatto, D., Berger, A., Gregory, C., and Rahn, M.: Metamorphic rates in collisional orogeny from in situ allanite and monazite dating, Geology, 37, 11-14, https://doi.org/10.1130/G25192A.1, 2009.

Janots, E., Berger, A., Gnos, E., Whitehouse, M. J., Lewin, E., and Pettke, T.: Constraints on fluid evolution during metamorphism from $\mathrm{U}-\mathrm{Th}-\mathrm{Pb}$ systematics in Alpine hydrothermal monazite, Chem. Geol., 326/327, 61-71, https://doi.org/10.1016/j.chemgeo.2012.07.014, 2012.

Janots, E., Grand'Homme, A., Bernet, M., Guillaume, D., Gnos, E., Boiron, M.-C., Rossi, M., Seydoux-Guillaume, A.-M., and De Ascenção Guedes, R.: Geochronological and thermometric evidence of unusually hot fluids in an Alpine fissure of Lauzière granite (Belledonne, Western Alps), Solid Earth, 10, 211-223, https://doi.org/10.5194/se-10-211-2019, 2019.

Keller, L. M., Hess, M., Fügenschuh, B., and Schmid, S. M.: Structural and metamorphic evolution of the CamugheraMoncucco, Antrona and Monte Rosa units southwest of the Simplon line, Western Alps, Eclogae Geol. Helv., 98, 19-49, https://doi.org/10.1007/s00015-005-1149-6, 2005.

Keller, L. M., Fügenschuh, B., Hess, M., Schneider, B., and Schmid, S. M.: Simplon fault zone in the western and central Alps: Mechanism of Neogene faulting and folding revisited, Geology, 34, 317-320, https://doi.org/10.1130/G22256.1, 2006.

Kirkland, C. L., Whitehouse, M. J., and Slagstad, T.: Fluid-assisted zircon and monazite growth within shear zones: a case study from Finnmark, Arctic Norway, Contrib. Mineral. Petr., 158, 637-657, https://doi.org/10.1007/s00410-009-0401-x, 2009.

Köppel, V. and Grünenfelder, M.: Concordant U-Pb ages of monazite and xenotime from the Central Alps and the timing of the high temperature Alpine metamorphism, a preliminary report, Schweiz. Miner. Petrog., 55, 129-132, 1975.

Kurz, W., Wölfler, A., Rabitsch, R., and Genser, J.: Polyphase movement on the Lavanttal Fault Zone (Eastern Alps): Reconciling the evidence from different geochronological indicators, Swiss J. Geosci., 104, 323-343, https://doi.org/10.1007/s00015011-0068-y, 2011.

Leu, W.: Lithostratigraphie und Tektonik der nordpenninischen Sedimente in der Region Bedretto-Baceno-Visp, Eclogae Geol. Helv., 79, 769-824, 1986.

Ludwig, K.: Isoplot v.3.75: A Geochronological Toolkit for Microsoft Excel, Berkeley Geochronology Center Special Publication, Berkeley, CA, 5, 1-75, 2012.

Mahon, K. I.: The New "York" Regression: Application of an improved statistical method to geochemistry, Int. Geol. Rev., 38, 209-303, https://doi.org/10.1080/00206819709465336, 1996.

Mancktelow, N. S.: Neogene lateral extension during convergence in the Central Alps: Evidence from interrrelated fault- 
ing and backfolding around the Simplonpass (Switzerland), Tectonophysics, 215, 295-317, https://doi.org/10.1016/00401951(92)90358-D, 1992.

Markley, M. J., Teyssier, C., Cosca, M. A., Caby, M. A., Hunsiker, J. C., and Sartori, M.: Alpine deformation and ${ }^{40} \mathrm{Ar} /{ }^{39} \mathrm{Ar}$ geochronology of synkinematic white mica in the SiviezMischabel Nappe, western Penninic Alps, Switzerland, Tectonics, 17, 407-425, https://doi.org/10.1029/98TC00560, 1998.

Meldrum, A., Boatner, L. A., Weber, W. J., and Ewing, R. C.: Radiation damage in zircon and monazite, Geochim. Cosmochim. Ac., 62, 2509-2520, https://doi.org/10.1016/S0016-7037(98)001744, 1998.

Meldrum, A., Boatner, L. A., Wang, S. J., Wang, S. X., and Ewing, R. C.: Effects of dose rate and temperature on the crystallineto-metamict transformation in the $\mathrm{ABO}(4)$ orthosilicates, Can. Mineral., 37, 207-221, 1999.

Meldrum, A., Boatner, L. A., and Ewing, R. C.: A comparison of radiation effects in crystalline $\mathrm{ABO}(4)$-type phosphates and silicates, Mineral. Mag., 64, 185-194, https://doi.org/10.1180/002646100549283, 2000.

Meyre, C., Marquer, D., and Schmid, S.M.: Syn-orogenic extension along the Forcola fault: correlation of Alpine deformations in the Tambo and Adula Nappes (Eastern Penninic Alps), Eclogae Geol. Helv., 91, 409-420, 1998.

Mullis, J.: P-T-t path of quartz formation in extensional veins of the Central Alps, Schweiz. Miner. Petrog., 76, 159-164, 1996.

Mullis, J., Dubessy, J., Poty, B., and O’Neil, J.: Fluid regimes during late stages of a continental collision: Physical, chemical, and stable isotope measurements of fluid inclusions in fissure quartz from a geotraverse through the Central Alps, Switzerland, Geochim. Cosmochim. Ac., 58, 2239-2267, https://doi.org/10.1016/0016-7037(94)90008-6, 1994.

Niggli, P., Königsberger, J., and Parker, R. L.: Die Mineralien der Schweizeralpen, 661 pp., B. Wepf \& Co, Basel, 1940.

Parrish, R. R.: U-Pb dating of monazite and application to geological problems, Can. J. Earth Sci., 27, 1431-1450, https://doi.org/10.1139/e90-152, 1990.

Pettke, T., Diamond, L. W., and Villa, I. M.: Mesothermal gold veins and metamorphic devolatilization in the northwestern Alps: The temporal link, Geology, 27, 641-644, https://doi.org/10.1130/00917613(1999)027<0641:MGVAMD>2.3.CO;2, 1999.

Price, J. B., Wernicke, B. P., Cosca, M. A., and Farley, K. A.: Thermochronometry across the Austroalpine-Pennine boundary, Central Alps, Switzerland: Orogen-perpendicular normal fault slip on a major "overthrust" and its implications for orogenesis, Tectonics, 37, 724-757, https://doi.org/10.1002/2017TC004619, 2018

Purdy, J. W. and Stalder, H. A.: K-Ar ages of fissure minerals from the Swiss Alps, Schweiz. Miner. Petrog., 53, 79-98, 1973.

Putnis, A.: Mineral replacement reactions: From macroscopic observations to microscopic mechanisms, Mineral. Mag., 66, 689708, 2002

Putnis, A.: Mineral replacement reactions, Reviews in Mineralogy and Geochemistry, 70, 87-124, 2009.

Rahn, M. K.: Apatite fission track ages from the Adula nappe: latestage exhumation and relief evolution, Schweiz. Miner. Petrog., 85, 233-245, https://doi.org/10.5169/seals-1662, 2005.
Ratschbacher, L., Frisch, W., Neubauer, F., Schmid, S. M., and Neugebauer, J.: Extension in compressional orogenic belts: the eastern Alps, Geology, 17, 404-407, https://doi.org/10.1130/00917613(1989)017<0404:EICOBT>2.3.CO;2, 1989.

Ratschbacher, L., Frisch, W., Linzer, H.-G., and Merle, O.: Lateral extrusion in the eastern Alps, Part 2: structural analysis, Tectonics, 10, 257-271, https://doi.org/10.1029/90TC02623, 1991.

Rauchenstein-Martinek, K.: Metamorphic fluid history along a cross section through the central Alps: constraints from LAICPMS analysis of fluid inclusions and Ar-Ar geochronology, PhD thesis, ETH Zürich, Zürich, 2014.

Rauchenstein-Martinek, K., Wagner, K. T., Wälle, M., Heinrich, C. A., and Arlt, T.: Chemical evolution of metamorphic fluids in the Central Alps, Switzerland: insight from LAICPMS analysis of fluid inclusions, Geofluids, 16, 877-908, https://doi.org/10.1111/gfl.12194, 2016.

Regis, D., Rubatto, D., Darling, J., Cenki-Tok, B., Zucali, M., and Engi, M.: Multiple Metamorphic Stages within an Eclogite-facies Terrane (Sesia Zone, Western Alps) Revealed by Th-U-Pb Petrochronology, J. Petrol., 55, 1429-1456, https://doi.org/10.1093/petrology/egu029, 2014.

Ricchi, E., Bergemann, C. A., Gnos, E., Berger, A., Rubatto, D., and Whitehouse, M. J.: Constraining deformation phases in the Aar Massif and the Gotthard Nappe (Switzerland) using Th-Pb crystallization ages of fissure monazite-(Ce), Lithos, 342-343, 223-238, https://doi.org/10.1016/j.lithos.2019.04.014, 2019.

Rolland, Y., Cox, S., Boullier, A. M., Pennacchioni, G., and Mancktelow, N.: Rare earth and trace element mobility in mid-crustal shear zones: insights from the Mont Blanc Massif (Western Alps), Earth Planet. Sc. Lett., 214, 203-219, https://doi.org/10.1016/S0012-821X(03)00372-8, 2003.

Rubatto, D., Gebauer, D., and Fanning, M.: Jurassic and Eocene subduction of the Zermatt-Saas-Fee ophiolites: implications for the geodynamic evolution of the Central and Western Alps, Contrib. Mineral. Petr., 158, 703-722, https://doi.org/10.1007/s004100050421, 1998.

Rubatto, D., Herrmann, J., Berger, A., and Engi, M.: Protracted fluid-induced melting during Barrovian metamorphism in the Central Alps, Contrib. Mineral. Petr., 158, 703-722, https://doi.org/10.1007/s00410-009-0406-5, 2009.

Ruffet, G., Gruau, G., Ballèvre, M., Féraud, G., and Phillipot, P.: $\mathrm{Rb}-\mathrm{Sr}$ and ${ }^{40} \mathrm{Ar}^{39}{ }^{39} \mathrm{Ar}$ laser probe dating of high-pressure phengites from the Sesia zone (Western Alps): underscoring of excess argon and new age constraints on the high-pressure metamorphism, Chem. Geol., 141, 1-18, https://doi.org/10.1016/S00092541(97)00052-1, 1997.

Sambridge, M. S. and Compston, W.: Mixture modeling of multi-component data sets with application to ionprobe zircon ages, Earth Planet. Sc. Lett., 128, 373-390, https://doi.org/10.1016/0012-821X(94)90157-0, 1994.

Schärer, U., Cosca, M., Steck, A., and Hunziker, J.: Termination of major ductile strike-sli shear and differential cooling along the Insubric Line (Central Alps), Earth Planet. Sc. Lett., 142, 331351, https://doi.org/10.1016/0012-821X(96)00104-5, 1996.

Schmid, S., Fügenschuh, B., Kissling, E., and Schuster, R.: The tectonic map and overall architecture of the Alpine orogen, Eclogae Geol. Helv., 97, 93-117, https://doi.org/10.1007/s00015004-1113-x, 2004. 
Seydoux-Guillaume, A.-M., Montel, J.-M., Bingen, B., Bosse, V., de Parseval, P., Paquette, J.-L., Janots, E., and Wirth, R.: Low-temperature alteration of monazite: Fluid mediated coupled dissolution-precipitation, irradiation damage, and disturbance of the U-Pb and Th-Pb chronometers, Chem. Geol., 330-331, 140158, https://doi.org/10.1016/j.chemgeo.2012.07.031, 2012.

Sharp, Z. D., Masson, H., and Lucchini, R.: Stable isotope geochemistry and formation mechanisms of quartz veins; extreme paleoaltitudes of the Central Alps in the Neogene, Am. J. Sci., 305, 187-219, https://doi.org/10.2475/ajs.305.3.187, 2005.

Stacey, J. and Kramers, J.: Approximation of terrestrial lead isotope evolution by a two-stage model, Earth Planet. Sc. Lett., 26, 207221, https://doi.org/10.1016/0012-821X(75)90088-6, 1975.

Steck, A. and Hunziker, J.: The Tertiary structural and thermal evolution of the Central Alps-compressional and extensional structures in an orogenic belt, Tectonophysics, 238, 229-254, https://doi.org/10.1016/0040-1951(94)90058-2, 1994.

Steck, A., Della Torre, F., Keller, F., Pfeifer, H.-R., Hunziker, J., and Masson, H.: Tectonics of the Lepontine Alps: ductile thrusting and folding in the deepest tectonic levels of the Central Alps, Swiss J. Geoci., 106, 427-450, https://doi.org/10.1007/s00015013-0135-7, 2013.

Steiger, R. H. and Jäger, E.: Subcommittee on Geochronology: Convention of the use of decay constants in geoand cosmochronology, Earth Planet. Sc. Lett., 36, 359-362, https://doi.org/10.1016/0012-821X(77)90060-7, 1977.

Surace, I. R., Clauer, N., Thélin, P., and Pfeifer, H.-R.: Structural analysis, clay mineralogy and $\mathrm{K}-\mathrm{Ar}$ dating of fault gouges from Centovalli Line (Central Alps) for reconstruction of their recent activity, Tectonophysics, 510, 80-93, https://doi.org/10.1016/j.tecto.2011.06.019, 2011.
Todd, C. S. and Engi, M.: Metamorphic field gradients in the Central Alps, J. Metamorph. Geol., 15, 513-530, https://doi.org/10.1111/j.1525-1314.1997.00038.x, 1997.

Townsend, K. J., Miller, C. F., D’Andrea, J. L., Ayers, J. C., Harrison, T. M., and Coath, C. D.: Low temperature replacement of monazite in the Ireteba granite, Southern Nevada: geochronological implications, Chem. Geol., 172, 95-112, https://doi.org/10.1016/S0009-2541(00)00238-2, 2000.

Van Gelder, I. E., Willingshofer, E., and Andriessen, P. A. M.: Miocene to recent kinematics and exhumation of the Mur-Mürz strike-slip fault (Eastern Alps) illustrating direct interplay with surrounding lithospheric scale processes. Poster at the Alpine Workshop 2015, Briançon, France, 2015.

Wiederkehr, M., Bousquet, R., Schmid, S. M., and Berger, A.: From subduction to collision: thermal overprint of HP/LP metasediments in the north-eastern Lepontine Dome (Swiss Alps) and consequences regarding the tectono-metamorphic evolution of the Alpine orogenic wedge, Swiss J. Geosci., 101, 127-155, https://doi.org/10.1007/s00015-008-1289-6, 2008.

Wiederkehr, M., Sudo, M., Bousquet, R., Berger, A., and Schmid, S. M.: Alpine orogenic evolution from subduction to collisional thermal overprint: The ${ }^{40} \mathrm{Ar} /{ }^{39} \mathrm{Ar}$ age constraints from the Valaisan Ocean, central Alps, Tectonics, 28, 1-28, https://doi.org/10.1029/2009TC002496, 2009.

Zwingmann, H. and Mancktelow, N.: Timing of Alpine fault gouges, Earth Planet. Sc. Lett., 223, 415-425, https://doi.org/10.1016/j.epsl.2004.04.041, 2004. 